\title{
The architecture of attention: Group structure and subsidiary autonomy
}

\author{
Sharon Belenzon* \\ Associate Professor of Strategy \\ Fuqua School of Business \\ Duke University \\ 100 Fuqua Drive \\ Durham, NC 27708-0120 \\ United States \\ sharon.belenzon@duke.edu
}

\begin{abstract}
Niron Hashai
Associate Professor of Strategy and International Business

Arison School of Business

The Intersicplinary Center

2 Kanfei Nesharim St.

Herzliya, 4610101

Israel

nhashai@idc.ac.il
\end{abstract}

\author{
Andrea Patacconi \\ Professor of Strategy \\ Norwich Business School \\ University of East Anglia \\ Norwich Research Park, Norwich NR4 7TJ \\ United Kingdom \\ A.Patacconi@uea.ac.uk
}

*- Corresponding author

Short running title: The architecture of attention

Keywords: Subsidiary autonomy, headquarters, organizational structure, attention-based view, corporate groups. 


\title{
The architecture of attention: Group structure and subsidiary autonomy
}

March 8, 2019

\begin{abstract}
Research summary. This paper examines the relationship between strategic decision-making at the subsidiary level and organizational structure. In many organizations, headquarters and subsidiaries are separated by intermediate subsidiaries. Building on the attention-based view of the firm, we argue that the greater the "organizational distance" of a focal subsidiary from headquarters (measured by the number of intermediate subsidiaries separating the subsidiary from headquarters), the lower the attention that headquarters devote to the subsidiary. Thus, subsidiary autonomy from headquarters increases with organizational distance. Using a large comprehensive dataset on the structure of corporate groups in Western Europe, we provide several pieces of evidence consistent with these hypotheses. By contrast, we find little support for the view that tall pyramids are created to magnify the voting control of large shareholders.
\end{abstract}

Managerial summary. Corporate groups - confederations of legally independent firms linked via ownership ties - are common around the world. An important function of headquarters in corporate groups is to allocate resources among member firms. We argue that, because headquarters mostly focus on allocating resources among units that they directly own, subsidiaries near the top of the group perform differently in response to changing external conditions than similar unaffiliated firms. This difference declines as one moves down the group pyramid, as lower-level affiliates receive less attention from headquarters. An analysis of a large comprehensive dataset on the structure of corporate groups in Western Europe supports these predictions. The paper suggests that the legal organization of groups is a useful instrument to channel limited headquarters attention to selected affiliates. 


\section{Introduction}

This paper examines the relationship between strategic decision-making at the subsidiary level and organizational structure. Recent work on the determinants of subsidiary autonomy has emphasized factors such as subsidiary capabilities and the balance of power between headquarters and subsidiaries (Martinez and Jarillo, 1989; Gupta and Govindarajan, 1991; Birkinshaw, 1996; Ambos, Andersson and Birkinshaw, 2010), but has largely neglected structural dimensions of organizational control emphasized in foundational work (Chandler, 1962; Lawrence and Lorsch, 1967; Stopford and Wells, 1972; Ghoshal and Nohria, 1989; Ghoshal and Bartlett, 1990; Ethiraj and Levinthal, 2004a).

Building on the attention-based view of the firm (March and Simon, 1958; Ocasio, 1997; Bouquet and Birkinshaw, 2008b; Bouquet, Morrison and Birkinshaw, 2009; Joseph and Ocasio, 2012), this paper makes two main contributions: (i) it provides a framework for understanding how managerial attention is distributed in corporate groups and (ii) presents three distinct pieces of evidence consistent with the proposed framework. Specifically, we propose that "organizational distance" — the number of intermediate subsidiaries separating a focal subsidiary from headquarters - is a useful construct to gauge the level of strategic autonomy that the focal subsidiary will enjoy.

Corporate groups - confederations of legally independent firms linked together via ownership ties — are a prevalent form of organization in both the developed and the developing world (La Porta, Shleifer and Lopez de Silanes, 1999; Khanna and Yafeh, 2007; Belenzon and Berkovitz, 2010). ${ }^{1}$ To a first approximation, corporate groups exhibit a pyramidal structure, with an "ultimate owner" (typically a wealthy family, a widely-held corporation, or the state) controlling chains of subsidiary firms. Headquarters perform two fundamental tasks in these structures: they allocate resources across units, and monitor the performance of these units (Bower, 1970; Collis,Young and Goold, 2007). Thus, headquarters attention in these structures can be conceptualized at least partly as the extent to which headquarters are involved in the allocation of budgets and in scrutinizing the subsidiaries' strategic plans. The less they are involved, the more the subsidiaries will enjoy autonomy, especially when it comes to large investment decisions.

We argue that, as groups expand into related and unrelated businesses, the complexity of managing a

\footnotetext{
${ }^{1}$ For instance, General Electric owns (directly or indirectly) 1,311 subsidiaries (21\% domestic) and is therefore part of a corporate group. The ten largest American industrial corporations own 5,113 subsidiaries, of which 33\% are domestic. The ten largest industrial British corporations own 4,669 subsidiaries (27\% are domestic), the ten largest French corporations own 7,821 subsidiaries (34\% are domestic), and the largest ten industrial German corporations own 5,214 subsidiaries (29\% domestic).
} 
diverse set of businesses will overwhelm the information processing capacity of headquarters (Chandler, 1962; Simon, 1962; Ethiraj and Levinthal, 2004a). To mitigate this problem, headquarters will selectively allocate their attention. Because the attention structure of an organization often echoes its formal structure (Joseph and Ocasio, 2012; Joseph and Wilson, 2018), we propose that greater organizational distance between a focal subsidiary and headquarters will be associated with lower levels of headquarters attention towards the subsidiary. Thus, organizationally distant subsidiaries will enjoy greater levels of autonomy than organizationally close subsidiaries.

Subsidiary autonomy may increase with organizational distance (measured by the number of intermediate affiliates separating the apex firm from the focal subsidiary) because: (i) organizational distance is inversely related to top management's interest and involvement in the subsidiary and (ii) organizational distance creates communication and governance frictions that reduce the effectiveness of central control (Stopford and Wells, 1972; Bethel and Liebeskind, 1998). Headquarters may delegate parenting responsibilities to intermediate units. However, the mandate of intermediate parents is likely to be restricted to specific industries and geographies (Stopford and Wells, 1972). Because subsidiaries near the bottom of the group pyramid are likely to be largely insulated from conditions in distant parts of the group (e.g., distant industries or geographies), we expect their behavior and performance to resemble those of similar standalone firms.

Using a large and comprehensive dataset on the internal structure and financial performance of about 40,000 groups in Western Europe covering the period 2002-2011, we provide several pieces of evidence consistent with these ideas. First, we show that organizational distance is positively related to the level of autonomy from headquarters that subsidiary managers report to enjoy, as measured by the World Management Survey (Bloom and Van Reenen, 2007). Second, organizational distance is also related to managerial practices that support decentralized decision-making at the subsidiary level, such as goal clarity and effective internal control mechanisms. Third, we examine the performance implications of greater autonomy. We argue that, if subsidiaries located lower down the group pyramid are more autonomous from headquarters than subsidiaries located higher up, then their response to changing industry conditions should be more similar to that of matched standalone firms than the response of higher-level subsidiaries. All these exercises provide strong support for our organizational distance hypothesis. The analysis also identifies several factors, including board interlocks, family ties and geographical proximity, that reduce but do not eliminate the effects of organizational distance. 
By contrast, we find little support for the widespread view that tall pyramids are created to magnify the control of large shareholders (Bebchuk, Kraakman and Triantis, 2000; Claessens, Djankov and Lang, 2000). Among the large groups in our sample, close to 70 percent are wholly- or almost wholly-owned by the ultimate shareholder. In the Netherlands and Great Britain this percentage is as high as 90 percent. Even in countries where "pyramiding" is widespread, such as Italy, more than $60 \%$ of all the large groups are wholly-owned. Thus, at least in Western Europe and for large groups, the "control-magnifying" view appears to have limited validity.

Our work has implications for organization theory and corporate restructuring. In a significant way, the attentional perspective advocated in this paper turns the standard, "control-magnifying" view of group structure on its head. The control-magnifying view holds that tall structures are created to magnify the voting control of large shareholders. Our attentional perspective emphasizes instead the greater autonomy of "organizationally distant" units. Thus, our attentional perspective suggests that tall pyramids attenuate, not magnify, the control exerted by ultimate shareholders.

Our work also contributes to research on subsidiary autonomy. The international business literature has engaged extensively with questions regarding the organization of the multinational corporation (MNC) (Stopford and Wells, 1972; Bartlett and Ghoshal, 1989), the centralization of decision-making (Gupta and Govindarajan, 1991) and the degree to which authority is delegated to foreign subsidiaries (Andersson, Forsgren and Holm, 2002; Birkinshaw, 1997; Birkinshaw and Morrison, 1995; Birkinshaw, Hood and Jonsson, 1998; Mudambi and Navara, 2004). However, this literature has typically assumed, either explicitly or implicitly, that foreign subsidiaries and headquarters interact directly, or at most through the mediation of one or two layers (e.g. Stopford and Wells, 1972). We contribute to this literature by exploring, for the first time to our knowledge, the link between subsidiary autonomy and the pyramidal structure of the intra-organizational network.

We do not claim that organizational distance has a causal effect on subsidiary autonomy. While communication and governance frictions suggest that such a causal relationship may exist, other factors such as lack of headquarters' interest in a subsidiary may also be correlated with both organizational distance and subsidiary autonomy. However, to the extent that organizational distance hinders headquarters' ability to meaningfully intervene in subsidiary matters, implications for corporate restructuring follow.

Consider the recent reorganizations at Airbus and Google. In 2016, Airbus merged its top entity, the Airbus Group, with its most important subsidiary, Airbus Commercial Aircraft, thereby reducing the 
organizational distance between these units. A goal of the merger was to allow top management to focus "more on the market for jetliners - which [was] booming, thanks largely to rising demand for air travel from the expanding middle classes in emerging economies" (Economist, 2016: 62-63). Conversely, in October 2015, Google partitioned its assets into several legally independent entities - the Alphabet group. In explaining the rationale behind this reorganization, founder Larry Page wrote: "[f]undamentally, we believe this allows us more management scale, as we can run things independently that aren't very related". ${ }^{2}$ The New York Times (2015) summarized Google's motives as follows: "Google Goal in Restructuring as Alphabet: Autonomy".

While Airbus and Google's motives for restructuring may be varied, these examples suggest that one objective may be to fine-tune attention structures. Airbus restructured so that top management could focus more on the commercial aircraft business. Google restructured (by creating a separate Alphabet headquarters) so that subsidiary managers could enjoy greater autonomy. Structure, through communication or other channels, may have an influence on attention, and this may be an important factor to consider in corporate restructuring.

\section{Theoretical framework}

\subsection{Organizational growth and divisionalization}

Many organizations grow by leveraging their capabilities in related markets (Teece, 1980; Prahalad and Bettis, 1986; Prahalad and Hamel, 1990; Anand and Singh, 1997). For instance, Du Pont started as a gunpowder manufacturer and then expanded into dynamite, smokeless powder, dyestuffs, synthetic fibers, plastics and countless other products. Google started as a search engine and then expanded into several other internet-related services and products, as well as smart phone devices, driverless cars, healthcare and so on.

Managing growth through diversification typically requires organizational change. Organizational structure (or architecture) refers to the set of rules, processes and communication channels that allow the organization to pursue its goals. A typical organizational response to growing complexity is hierarchical decentralization. Simon $(1947,1962)$ and March and Simon (1958) note that complex social systems are almost inevitably hierarchically organized, both to keep individual tasks manageable and to improve the

\footnotetext{
${ }^{2}$ From Larry Page, 2015, Google Announces Plans for New Operating Structure. Available at https://abc.xyz/investor/news/releases/2015/0810.html
} 
resilience of the overall system. Because humans are bounded in their ability to process information, organizations must create structures and procedures that channel information to the relevant decisionmakers and guide their problem-solving activities (Simon, 1947; Williamson, 1981; Ethiraj and Levinthal, 2004a; 2004b; Stan and Puranam, 2017). Hierarchy, division of labor, indoctrination and work practices are examples of such structures and procedures.

Decentralization is often achieved through divisionalization. In a multidivisional structure, the organization is divided into several units responsible for specific products, customers, or regions. The units are relatively autonomous, with divisional managers holding substantial decision-making authority within the limits set by headquarters. An advantage of the multidivisional structure is that it allows for a division of managerial attention, with headquarters focusing on strategic planning and oversight, and business units focusing on more operational matters (Chandler, 1962). ${ }^{3}$

Both large diversified firms and corporate groups are often organized as multidivisional structures (Chandler, 1962; Chang and Choi, 1988). Take for instance the Liebherr Group. The Liebherr Group comprises more than 130 subsidiaries owned, directly or indirectly, by a central holding company, LiebherrInternational AG. The central holding company fulfills directing, coordinating and monitoring functions. The top management team, in particular, decides on financial and investment policy. The subsidiaries are divided into eleven product divisions (e.g., Aerospace and transportation systems, Components, and Concrete technology), each headed by a divisional controlling company (e.g., Liebherr-Aerospace \& Transportation SAS, Liebherr-Component Technologies AG, and Liebherr-Mischtechnik GmbH). The product divisions enjoy vast operational autonomy. ${ }^{4}$

Like multidivisional firms, corporate groups are often created to exploit economies of scale and scope. Groups benefit from redeploying financial, managerial and technological resources across units, especially when external markets function poorly (Leff, 1978; Khanna and Yafeh, 2007; Belenzon and Berkovitz, 2010; Belenzon, Berkovitz and Rios, 2013). The fundamental difference between corporate groups and multidivisional firms is that, in corporate groups, units are organized as legally independent firms (i.e.,

\footnotetext{
${ }^{3}$ Subsequent work has clarified that this division of managerial attention is a matter of degree. For instance, Freeland (1996) demonstrates that involvement of business units in strategic decision-making at General Motors was much more extensive than one may have expected, and actually produced better results than when strategic and operational decisionmaking were more clearly separated. An extensive literature in international business emphasizes the role of subsidiary initiatives in multinational corporations (Birkinshaw, 1997; Birkinshaw et al., 1998) and highlights contingencies under which subsidiaries are granted more or less autonomy from headquarters (Martinez and Jarillo, 1989; Gupta and Govindarajan, 1991).

${ }^{4}$ See the Liebherr Group's website at https://www.liebherr.com.
} 
subsidiaries), while in multidivisional firms, units are organized as (unincorporated) divisions. In general, a firm can incorporate some of its units and keep others as divisions. The choice between setting up a subsidiary and a division (i.e., between incorporating a unit or not) depends on many factors, including tax, legal, informational and tradability considerations (Ayotte and Hansmann, 2012; Kandel, Kosenko, Morck and Yafeh, 2015; Belenzon, Lee and Patacconi, 2018). Belenzon et al. (2018), for instance, show that groups tend to set up more subsidiaries in countries where parent and sister companies are less likely to be held liable for the losses of other group affiliates. New Deal reforms such as the Investment Company Act of 1940 and the intercorporate dividend tax also affected ownership structure in the US, leading to the demise of many large corporate groups (Kandel et al., 2015).

Less fundamentally, corporate groups and multidivisional firms also differ because, while a firm wholly owns all its divisions, a group may only partly own some of its subsidiaries. Indeed, it is often argued that powerful owners create tall pyramids of partly-owned affiliates to control corporate assets worth considerably more than their nominal ownership rights (Bebchuk et al., 2000; Claessens et al., 2000). This separation of ownership and control can give rise to important agency problems. The controlling shareholders can, for instance, in collusion with management, transfer resources from subsidiaries where they have low cash-flow rights (usually at the bottom of the pyramid) to subsidiaries where they have higher cash-flow rights (usually, near the apex of the pyramid), to the detriment of minority shareholders (Johnson, La Porta, Lopez-de Silanes and Shleifer, 2000; Morck, Wolfenzon and Yeung, 2005; Almeida and Wolfenzon, 2006). Thus, tall pyramids may be created with a "control-magnifying" or "tunneling" intent.

\subsection{The allocation of attention in groups}

In this paper, we build on the premise that pyramidal groups originate from a historical process of growth through diversification and examine how headquarters allocate their attention among their subsidiaries. Following Bouquet, Morrison and Birkinshaw (2009: 110), we define the attention of a group of managers as a "collective investment of time and effort that is situated within an entire system of activities, communications, and discussions".

Headquarters perform two fundamental functions in multidivisional organizations: entrepreneurial and administrative (Chandler, 1962, 1991). The entrepreneurial function involves strategic planning and resource allocation - to govern the development, allocation and deployment of resources within the 
hierarchy (Bower, 1970; Collis, et al., 2007). The administrative function is concerned with monitoring the performance of the operating divisions and checking on the use of the resources allocated. These two functions are obviously intertwined: planning and resource allocation cannot properly be performed without some knowledge and monitoring of internal operations. Ambos et al. (2010: 1103) similarly highlight the monitoring function of headquarters, which comprises of "formal control mechanisms and the allocation of budgets and resources" through, for instance, "closer scrutiny of [the subsidiary's] strategic plans, and [...] a higher frequency of visits".

Given the importance of the resource allocation task, headquarters attention can be conceptualized at least partly as the extent to which headquarters are involved in the allocation of budgets and in scrutinizing the subsidiaries' strategic plans. Significant resource allocation and financial review responsibilities are located at the central or divisional headquarters level, arguably because these tasks require specialized staff that would be very costly to duplicate elsewhere within the group pyramid (Goold and Campbell, 2002). For instance, Chang and Choi (1988) document that, among the thirty largest Korean corporate groups, most (twenty-four) possess a general corporate planning office (or its equivalent) at the group level, which can effectively control affiliated firms.

We argue that the more headquarters are involved in allocating budgets and resources to a focal subsidiary, the less autonomy the managers of the subsidiary will enjoy. When internal resource redeployment is substantial, subsidiary managers cannot base their decisions solely on 'local' conditions (their own demand, borrowing capacity, etc.), but must instead also take intra-group transfers into account. Autonomy, especially investment autonomy, is constrained, because headquarters can transfer funds from one unit to another. By contrast, when internal resource redeployment is not important, headquarters' influence is reduced. Subsidiaries will have to rely on their own resources, and their performance will more closely resemble that of similar standalone firms. ${ }^{5}$

\subsubsection{Organizational distance and subsidiary autonomy}

As groups grow in size and complexity, headquarters will not be able (and sometimes will not wish) to devote the same level of attention to all subsidiaries. They will have to allocate their attention selectively. Building on the insight that "organizational architecture structurally distributes managerial attention

\footnotetext{
${ }^{5}$ Of course, resource allocation is not the only form of headquarters attention. For instance, headquarters may help a subsidiary evaluate potential alliance partners or potential targets for an acquisition (we thank an anonymous referee for suggesting these examples). These forms of attention may or may not constrain the autonomy of the subsidiary. However, our discussion will focus on the resource allocation role of headquarters.
} 
throughout the firm" (Joseph and Ocasio, 2012: 635; Ocasio, 1997; Joseph and Wilson, 2018), we propose that the structure of a group will often reflect the allocation of attention within the group. Specifically, we introduce the concept of "organizational distance" - the number of intermediate subsidiaries separating a focal subsidiary from headquarters - and argue that organizational distance is negatively related to headquarters attention toward the focal subsidiary. Thus, as organizational distance between headquarters and the subsidiary increases, the subsidiary will tend to enjoy more autonomy.

Subsidiary autonomy may increase with organizational distance for a number of reasons. First, organizational distance is likely to be inversely related to top management's interest and involvement in a subsidiary. Units that are strategically important and generate or require significant cash are likely to be owned and monitored directly by central or divisional headquarters. Units that are less strategically important may be located lower down the group pyramid.

Organizational distance may also affect subsidiary autonomy because communication and governance frictions hinder headquarters' ability to monitor and control organizationally distant subsidiaries. Communication frictions are delays and distortions that arise when information is transmitted through communication channels (Stopford and Wells, 1972; Dessein, 2002; Patacconi, 2009). The greater the distance between two units, as measured by number of intermediaries a message has to go through, the greater the chance that delays or distortions will occur. If these delays or distortions are severe enough, headquarters may choose to relinquish control and grant subsidiaries more autonomy or subsidiaries may de facto become more autonomous in their decision-making.

Governance frictions occur instead when subsidiary managers use their discretion or weaknesses in the group's internal control systems to take actions that are suboptimal for the group as a whole. This occurs when subsidiaries do not fully internalize the effects of their actions on other group affiliates (Stopford and Wells, 1972; Alonso, Dessein and Matouschek, 2008). For instance, subsidiary managers may be reluctant to take actions that impose costs on their own units while delivering benefits mostly to other units. Governance frictions can be particularly severe when subsidiaries have minority shareholders (Bethel and Liebeskind, 1998), because in most jurisdictions managers are required by law to protect the interests of the shareholders of their own firm, not the interests of the controlling group. Moreover, unlike managers of unincorporated units, subsidiary managers have formal CEO titles and clearly separated profits and losses. As such, they may enjoy more autonomy, and may use this autonomy to protect the interests of their firms. 
Because governance frictions can occur at each level of the group pyramid, headquarters' loss of control is likely to be particularly severe near the bottom of the pyramid. As Stopford and Wells (1972: 13) emphasize: "[governance] costs are likely to increase as the number of levels in the hierarchy increases: the greater the number of levels, the greater is the possibility of suboptimal response". Note that, if subsidiaries increasingly fail to internalize group-level externalities as one moves down the pyramid, we should expect subsidiary behavior and performance to increasingly resemble those of standalone firms as organizational distance increases.

In short, we suggest that, (i) because organizational distance is inversely related to top management's interest and involvement in a subsidiary, and (ii) communication and governance frictions reduce the effectiveness of headquarters' control, subsidiaries located near the bottom of the group pyramid will enjoy greater autonomy from headquarters than subsidiaries located near the top.

Hypothesis 1. Subsidiary autonomy from headquarters increases with organizational distance.

\subsubsection{Managerial practices supporting decentralization}

If organizationally distant subsidiaries operate quasi-autonomously with little involvement from central headquarters, then we would also expect these subsidiaries to exhibit managerial practices that support decentralized decision-making.

In choosing to what extent to grant autonomy to a focal subsidiary, headquarters face a key trade-off. On the one hand, if headquarters is more involved in a subsidiary's plans and operations, then it may not be able to devote the same level of attention to other subsidiaries or tasks. For instance, Schoar (2002) finds that acquisitions shift top management's attention to the acquired units, to the detriment of existing divisions (a 'new toy' effect). The overall effect is negative because, although the productivity of the new units increases, the productivity of the old units (which are much more numerous) declines.

On the other hand, if headquarters grants more autonomy to a subsidiary, agency problems may arise. Subsidiary managers may engage in 'empire building' (Harris and Raviv, 1996) or may avoid making difficult decisions, such as denying workers pay rises or shutting down old plants, preferring instead to enjoy a 'quiet life' (Bertrand and Mullainathan, 2003). Even headquarters' ability to intervene ex post may be compromised, because headquarters' ability to fully understand the implications of subsidiary decisions may be reduced (Baysinger and Hoskisson, 1990; Hoskisson, Hitt and Hill, 1993).

Before decision-making authority can be decentralized, therefore, headquarters must make sure that 
subsidiaries can operate autonomously in an effective manner. Clear goals must be provided, and rigorous internal controls must be established (Williamson, 1991; Hoskisson, Hitt and Hill, 1993). Thus, we expect organizational distance, to the extent that it is correlated with greater autonomy, to be also correlated with managerial practices that support decentralized decision-making, such as goal clarity and effective internal control mechanisms.

Hypothesis 2. Organizational distance is positively related to managerial practices that support decentralized decision-making, such as goal clarity and effective internal control mechanisms.

\subsubsection{Resource allocation, organizational distance, and responsiveness to changing industry conditions}

If headquarters pay less attention to subsidiaries located lower down the pyramid and their management exhibits more autonomous decision-making, then we should also expect their performance to more closely resemble that of matched standalone firms. That is, the effect of group membership, originating from headquarters' resource allocation role, should diminish as we move down the group pyramid.

Two important points must be emphasized here. The first point concerns how headquarters allocate resource in response to changing industry conditions. The literature has highlighted two different ways in which internal capital markets may operate. These views may be labeled "winner picking" and "coinsurance".

Winner picking theory holds that headquarters use their superior knowledge or information from subsidiaries to allocate resources to the most promising units (Williamson, 1975; Stein, 1997; Ozbas, 2005). According to this view, multidivisional organizations exist precisely because their headquarters can allocate resources more efficiently than external capital markets. Winner picking theory suggests that headquarters will transfer resources from units operating in declining industries to units operating in growing industries. Thus, group membership will tend to magnify the impact of changing industry conditions on subsidiary performance.

A different view is that headquarters support or "prop up" poorly performing units. Risks are shared among group affiliates by smoothing out income flows and by reallocating resources from cash-rich units to poorly performing units (Chang and Hong, 2000; Ferris, Kim and Kitsabunnarat, 2003; Khanna and Yafeh, 2005). Chang and Hong (2000), for instance, show that debt guarantees, equity investments and internal trade are extensively used within Korean groups for cross-subsidization purposes. A key benefit 
of co-insurance is that bankruptcy risk and subsidiaries' cost of debt can be reduced (Lewellen, 1971; Byun, Choi, Hwang and Kim, 2013). In addition, co-insurance may prevent the liquidation of promising units hit by temporary adverse shocks (e.g., a recession). The downside of co-insurance is that funds may be missallocated, especially if headquarters make decisions based on political rather than economic considerations (Milgrom and Roberts, 1988; Meyer, Milgrom and Roberts, 1992).

Co-insurance theory suggests that headquarters will allocate more resources to units operating in declining industries, and fewer resources to units operating in growing industries, than external capital markets would. Thus, group membership will tend to dampen (not magnify) the impact of changing industry conditions on subsidiary performance.

The key point here is that, regardless of which effect is predominant (winner picking or co-insurance), if headquarters pay less attention to subsidiaries located lower down the pyramid, then the magnitude of the group membership effect will diminish with organizational distance.

A second important point is that headquarters may delegate resource allocation responsibilities for organizationally distant subsidiaries to intermediate parents. Indeed, authority is often distributed in complex organizations (Bartlett and Ghoshal, 1989; Goold and Campbell, 2002; Birkinshaw, Braunerhjelm, Holm and Terjesen, 2006; Piekkari, Nell and Ghauri, 2010). However, the functions of intermediate parents are likely to be restricted to the specific industry or region over which they have purview (Stopford and Wells, 1972). To the extent that the 'relevant' parent and the focal subsidiary share common characteristics, the impact of extraneous conditions on the focal subsidiary may be reduced, leaving it largely insulated from conditions in distant parts of the group. In the case of the Liebherr Group, for instance, lower level subsidiaries in the Domestic Appliances division headed by Liebherr-Hausgerate GmbH will mostly be responsive to conditions prevailing in their industry, not to conditions prevailing in other industries where the group operates (e.g., Components, Concrete technology, Cranes).

The arguments above suggest that the effect of group membership, originating from headquarters' resource allocation role, should diminish as we move down the pyramid. Thus, within a group, the performance of lower-level subsidiaries should more closely resemble that of matched standalone firms than the performance of higher-level subsidiaries.

Hypothesis 3. As organizational distance increases, the performance of group affiliates in response to changing industry conditions increasingly resembles that of matched standalone firms. 


\subsubsection{Moderating factors}

The previous hypothesis states that, as we move down the pyramid, performance differences between group affiliates and standalone firms are attenuated, because headquarters become less involved in allocating resources to these organizationally distant subsidiaries. However, organizational distance is at best only a crude proxy for headquarters attention. For instance, if headquarters and the subsidiary are in the same industry, headquarters may devote more attention to the subsidiary and communication and governance frictions may be lower, even if the subsidiary and headquarters are organizationally distant. Similarly, if a subsidiary is managed by a member of the family that controls the group, communications between the subsidiary and headquarters may remain good regardless of organizational distance. Governance frictions may also be reduced, as family members are likely to take actions that are optimal for the group as a whole, instead of just focusing on subsidiary performance.

These considerations suggest that subsidiary characteristics associated with greater "closeness" between headquarters and a focal subsidiary will tend to reduce the effects of organizational distance on subsidiary performance. Characteristics associated with greater closeness may include social ties among managers (for instance due to family relationships or same ethnicity), board overlaps, and industrial or geographical proximity.

Hypothesis 4. Subsidiary characteristics associated with greater closeness between headquarters and a focal subsidiary reduce the effects of organizational distance on subsidiary performance.

\section{Data}

This paper combines data from two main sources: (i) ownership and accounting data for corporate groups from the Amadeus and Icarus databases compiled by Bureau Van Djik, and (ii)firm-level information on managerial autonomy from the World Management Survey (Bloom and Van Reenen, 2007).

We define a corporate group as a confederation of two or more legally independent firms that are controlled by the same ultimate owner (an individual, a family, or a widely-held corporation). ${ }^{6}$ Control over a subsidiary can be exerted either directly or indirectly through a tall pyramidal structure. For example, suppose that owner A controls firm B, which in turn controls firm C. In that case, we say that A indirectly controls firm C. The pyramidal structure of a group consists of all the parent-subsidiary control

\footnotetext{
${ }^{6}$ We exclude from our sample firms where the ultimate owner is the state.
} 
chains that originate from the same ultimate owner. The procedure to construct pyramidal structures using raw ownership data is discussed in the next subsection; further details are provided in the Appendix.

The analysis focuses on West European corporate groups. The source of firm-level accounting information is the Company Register House in each of the countries in our sample. The key advantage of this data is the large coverage of firms, especially private firms. Some of our groups have subsidiaries located outside Western Europe. When we have data on these subsidiaries (e.g., subsidiaries in Eastern Europe, or the United States), we include this information in our sample. To avoid including economically insignificant groups, we drop groups that hold less than 10 million dollars in total assets, or only have two or fewer subsidiaries. This leaves us with 53,944 groups in 15 West European countries. Of these groups, $29 \%$ of the groups are British, 19\% are French, $8 \%$ are German, 7\% are Spanish and 5\% are Italian. The remaining groups are from Norway, Sweden, Finland, Denmark, Ireland, Belgium, Netherlands, Switzerland, Portugal and Greece.

\subsection{Constructing the group's pyramidal structure}

We develop an algorithm to determine the structure of corporate groups based on the Amadeus and Icarus ownership databases. The algorithm consists of two parts: (i) a control-chain generator that constructs the control links among subsidiaries (the parent-subsidiary chains) and (ii) a name matching procedure that groups together firms controlled by the same ultimate owner.

A shareholder is assumed to have direct control over a firm if it owns a sufficiently large equity stake in that firm. We make the following assumptions regarding direct control. For private firms, we say that shareholder A (an individual, a family, or a firm) controls firm B if A owns more than 50 percent of firm B. For public firms, we assume control if the equity stake is larger than 20 percent. The lower threshold for public firms reflects the fact that ownership is typically much less concentrated in public firms than in private firms. Thus, a lower equity stake is often sufficient to exert control in public firms.

The raw ownership database includes 843,390 ownership links that satisfy these control assumptions, where 406,379 shareholders control 843,124 subsidiaries. The average percentage of ownership is 94.6 with

a median of 100 (77 percent of the ownership links involve wholly-owned subsidiaries). There are 2,484 public subsidiaries. For these subsidiaries, the average percentage of ownership is 53.6 with a median of 49.

Using these direct control links, the algorithm constructs parent-subsidiary control chains. Consider a 
situation where shareholder A controls firms B and C, and firm B controls firm D. The algorithm creates the control chains A-B-D and A-C. Then the algorithm merges together all the control chains that refer to the same ultimate owner (in this case, A). The ultimate owner can either be a widely-held corporation or a family (where a "family" can be an individual shareholder). Aggregating individual shareholders into families is not straightforward. We use information about surnames, and assume that if different individuals share the same surname, they belong to the same family. ${ }^{7}$

An important definition is that of apex firm. The apex firms of a group are all the affiliates of the group that have no corporate controlling shareholders (but may have family controlling shareholders). If the ultimate owner of a group is a widely-held corporation, then there is only one apex firm: the widelyheld corporation. This is in fact the only group affiliate that has no corporate controlling shareholders (and is obviously located at the top of the group). By contrast, if the group's ultimate owner is a family, there can be multiple apex firms. These apex firms are located at the top of each of the parent-subsidiary chains controlled by the family. For instance, suppose a family directly controls firms $\mathrm{A}_{1}$ and $\mathrm{A}_{2}, \mathrm{~A}_{1}$ controls firm $B_{1}$, and $A_{2}$ controls firm $B_{2}$. Then $A_{1}$ and $A_{2}$ are apex firms. By convention, all apex firms are located at level 1. Affiliates directly controlled by level 1 firms are located at level 2 (e.g., firms $\mathrm{B}_{1}$ and $\mathrm{B}_{2}$ ). Affiliates directly controlled by level 2 firms are at level 3 , as so on. We call all the affiliates that are not apex firms 'subsidiaries'. There is a simple relationship between organizational distance and the ownership level of a subsidiary. Organizational distance is ownership level minus one. ${ }^{8}$

An important issue is how to deal with cross-holdings. Because we made restrictive control assumptions, cross-holdings are rare in our sample. Our algorithm flags cross-holdings, but only $0.5 \%$ of the ownership chains in our sample include one or more cross-holdings. As there is no clear ordering of firms in a cross-holding ownership chain, we eliminate these chains from our final sample. Further details on the algorithm are provided in the online appendix.

\footnotetext{
${ }^{7}$ The name matching process deals with three important issues. First, ultimate owner names are not standardized, i.e., the same name can be spelled differently across subsidiaries. Second, common names may lead to 'over-grouping'. Third, for wealthy families, we frequently observe that different members control different firms at the top of a control chain. Thus, we have to determine whether to group firms at the family level or at the individual level. We deal with these issues as follows. First, we develop a name standardization procedure that harmonizes the different string patterns in the data. Second, we search for publicly available information on each of our largest 500 corporate groups. When we cannot verify from public sources (such as Forbes and The Economist) that a given family is indeed wealthy, we check for name commonality. We compute the frequency of the appearance of the name in the complete population of ultimate owner names. In case this frequency is higher than the median frequency, we assume the common name problem and do not group ultimate owners. In these cases, the ultimate owner of a group is the leading shareholder. Third, even when different family members control different firms at the top of a control chain, we group chains at the family level.

${ }^{8}$ In the econometric analysis, we aggregate all apex firms under the same ultimate owner. The regressions are within groups, which means within ultimate owners, not apex firms.
} 


\subsection{Descriptive Statistics}

Table 1 presents summary statistics for corporate group subsidiaries that are included in the main econometric analysis. The average 3-year growth rate of these subsidiaries is $41 \%$ with a median of $22 \%$, a 10th percentile of $-54 \%$ and a 90 th percentile of $70 \%$ (our sample includes the 2008-2009 great recession, a fact which explains why a considerable fraction of firms have contracted over time). Average firm sales are $\$ 96$ million (a median of $\$ 4.8$ million) and average number of employees is 434 (a median of 36 ). The average corporate group has 40 subsidiaries and controls close to $\$ 5$ billion worth of sales.

Table 2 shows how subsidiary characteristics vary across ownership levels. Most subsidiary characteristics remain stable across ownership levels: 3-year sales growth, sales, assets, number of employees, return on assets, cash flow and direct equity stakes at the subsidiary level all remain similar across ownership levels. The only exception is the percentage of publicly traded firms which drops with ownership level.

\section{[Insert Tables 1 and 2 here]}

Figures 1a and $1 \mathrm{~b}$ present the distribution of group assets in our sample by corporate group depth. Corporate group depth is defined as the maximum ownership level of the subsidiaries of a group. About $20 \%$ of assets are controlled by corporate groups with depth 2 or 3 . The mode of the distribution is 6 : groups with depth 6 control $18.5 \%$ of the assets in our sample. About $55 \%$ of the assets in our sample are controlled by groups with depth 6 or more: tall groups appear to be economically important. The red dotted line represents assets controlled by family-owned groups as a percentage of the total assets controlled within each level. Contrary to the view that tall groups are typically created by wealthy families to magnify their voting power, this percentage declines with group depth. The ultimate owners of the tallest groups tend to be widely-held corporations. This most likely reflects the fact that depth and assets are positively correlated, and family ownership tends to decline with group size (as measured by assets).

Figure 1b shows that tall groups are important in most countries in our sample. Interestingly, tall groups are especially prominent in the UK and France (in the UK, $24 \%$ of assets are held by groups of depth 8 and in France, $36 \%$ of assets are held by groups of depth 6 ). This fact is hard to reconcile with the control-magnifying view. The control-magnifying view would suggest that the incentives to create tall groups are greater in countries with weak minority shareholder protection, such as Italy or Spain, because in those countries tunneling would be easier. By contrast, tall groups appear to be particularly prominent in countries with strong minority shareholder protection and good corporate governance practices, such 
as the UK.

\section{[Insert Figures 1a and 1b here]}

Next, we examine the extent to which economic activity within a corporate group is organized near the bottom of the pyramid. For each group we calculate the share of assets at each ownership level over all the assets held by the group and average these assets across groups with the same depth. For instance, in Figure 2, the upper left figure plots the cumulative distribution of assets for corporate groups with depth 2. For these groups, $54 \%$ of assets are located at level 1 (the apex firm level) and the remaining $64 \%$ of assets are located at level 2. The lower left figure plots the cumulative distribution of assets by levels for corporate groups with depth 5. For these groups, only $13 \%$ of assets are located at level 1, 55\% of assets are located at level 3 and above, and $23 \%$ of assets are located at levels 4 and 5 . Lastly, the bottom right figure plots the distribution of assets by level for corporate groups with depth 7 . For these groups, $68 \%$ of assets are located at levels 3 and above, and $33 \%$ of assets are located at levels 4 and above. Taken together these plots indicate that a significant share of group assets is located in lower-level subsidiaries, suggesting that a large share of the groups' economic activity occurs near the bottom of the pyramid.

\section{[Insert Figure 2 here]}

\section{Pyramidal structure and minority owners}

The pattern that emerges from Figures 1 and 2 is that tall pyramids are economically important and that, within corporate groups, a significant portion of economic activity takes places near the bottom of the pyramid. But why are these tall pyramids created? A popular view, which we label the "controlmagnifying" view, holds that tall pyramids are created by large shareholders to extend their control over vast "empires" while committing only limited resources. According to this view, pyramiding is a legal device that helps separate ownership and control. This separation becomes more and more extreme as one moves down the pyramid.

In this section, we examine the relevance of the control-magnifying view in our sample of large Western European groups. We focus on groups with annual sales of at least $\$ 100$ million, where the results are more striking. We find very little support for the view that tall pyramids are created to magnify the control of large shareholders. 
Figure 3 presents the distribution of wholly-owned groups by country and ultimate owner type. A group is classified as wholly-owned (or almost wholly-owned) if the ultimate owner of the group owns on average at least $95 \%$ of the group affiliates' equity. Western European groups are often wholly-owned by their ultimate owners. As Figure 3a shows, nearly 70 percent of corporate groups in the large group sample are wholly-owned. In the Netherlands and Great Britain, this percentage is as high as 90 percent. Even in countries where "pyramiding" is widespread, such as Italy, more than $60 \%$ of groups are wholly-owned. Figures $3 \mathrm{~b}$ distinguish between family-owned and widely-held groups. A large proportion of groups in each subsample remains wholly-owned, although results are weaker for family-owned groups.

\section{[Insert Figure 3 here]}

Finally, we examine whether the ownership stake of the ultimate owner decreases as we move down the pyramid. Supporting our previous findings of very high ownership concentration in most large groups, we do not observe a declining ownership stake pattern in our data. As Figure 4a shows, for ownership level 2, average equity held by the ultimate owner is $95 \%$, and $86 \%$ of these ownership links capture wholly-owned relationships. The percentage of equity remains quite stable even when we reach level 6 and beyond. Figure 4b presents the same pattern separately for each of the main countries in our sample. While there is some variation across countries, the main findings are robust. In every country, the majority of ownership links denote full ownership (100 percent equity stake) and the average share of equity stakes owned by the ultimate owner remains quite stable as we move down the pyramid.

\section{[Insert Figures $4 \mathrm{a}$ and $4 \mathrm{~b}$ here]}

The conclusion we draw from Figures 3 and 4 is that, at least for large groups in several Western European countries, the "control-magnifying" view of corporate group structure has limited validity. Enabling the separation of ownership and control does not appear to be a major reason for the creation of tall corporate groups in this sample.

\section{Pyramidal structure and subsidiary autonomy}

In Section 2, we argued that the structure of a group often reflects the allocation of managerial attention within the group. The greater the organizational distance of a focal subsidiary from headquarters, the less attention headquarters will devote to that subsidiary, and hence the greater the level of autonomy 
that the subsidiary will enjoy. In this section, we present several pieces of evidence consistent with this idea.

\subsection{Evidence from the World Management Survey}

The first piece of evidence relies on survey data. The World Management Survey (WMS) (Bloom and Van Reenen, 2007; Bloom, Sadun and Van Reenen, 2012) provides detailed firm-level information on the perceived level of autonomy of subsidiary managers from central headquarters (CHQ). Plant managers, often operating in legally independent subsidiaries, were asked questions about their perceived level of autonomy in investment, hiring, production, and marketing decisions from CHQ. We merge WMS data with our data on pyramidal structure to examine whether the perceived level of autonomy of a focal subsidiary manager is positively associated with organizational distance, as measured by the subsidiary's ownership level.

The WMS sample includes 2,185 European firms (42\% from Great Britain, 17\% from Germany, 17\% from France, 10\% from Italy, 9\% from Italy and the remaining from Northern Ireland). We match $71 \%$ of the firms in WMS to our corporate group sample. Based on our control assumptions, 29\% of the WMS firms are standalone firms, which we exclude from the analysis. The average WMS subsidiary is located at level 3.2 with a median of 3 .

We examine whether the organizational distance between a subsidiary and the apex firm (as measured by the subsidiary's ownership level) is positively associated with subsidiary autonomy (Hypothesis 1). To measure subsidiary autonomy, we use several questions from the WMS: (i) the number of hierarchical layers that separate a subsidiary manager from central headquarters, which we assume is located in the apex firm (WMS label: level2ceo); (ii) the percentage of headquarters managers that are on subsidiary site (WMS label: onsite); and (iii) four dimensions of business unit autonomy: (a) hiring autonomy (WMS label: central4), (b) investment autonomy (WMS label: lcentral5), (c) sales and marketing autonomy (WMS label: central6), and (d) new product introduction autonomy (WMS label: central7). Higher scores for questions (i) and (iii), and lower scores for question (ii), imply greater autonomy for the subsidiary.

Consistent with Hypothesis 1, Table 3 shows a positive correlation between organizational distance and survey measures of subsidiary autonomy. In all specifications, we control for equity stakes held by the ultimate owner, employment, age, total number of subsidiaries in the group, and complete sets of country and two-digit SIC code fixed-effects. 
Column 1 shows a strong positive relationship between ownership level and the survey measure of the number of hierarchical layers that separate the subsidiary manager from CHQ. Column 2 examines the relationship between the percentage of firms that report that headquarters managers are on subsidiary site and ownership level, and shows a strong negative correlation between these two measures. Based on the estimate from Column 1, moving from the apex firm (level 1) to a level 3 subsidiary is associated with an increase of 3.6 reported hierarchy levels, the same as the sample average hierarchy levels. Based on the estimate from Column 2, moving from the apex firm (level 1) to a level 3 subsidiary is associated with a decrease of 0.21 in the share of firms that report $\mathrm{CHQ}$ managers are on site (30\% of sample average value).

Column 3 examines the relationship between ownership level and the subsidiary's aggregate response to the autonomy questions (WMS label: central). There is a positive and statistically significant relationship between subsidiary autonomy and ownership level. Moving from the apex firm to a level 3 subsidiary yields a $50 \%$ increase in the autonomy score, relative to the average sample response. Columns 4-7 explore in more detail which functions subsidiaries located lower down in the ownership chain are granted greater autonomy, relative to subsidiaries closer to CHQ. We find that the positive relationship between ownership level and autonomy is driven by investment autonomy. Moving from the apex firm to a level 3 subsidiary is associated with $48 \%$ increase in the largest capital investment that subsidiaries can make without prior authorization from CHQ (an additional $\$ 26$ million).

\section{[Insert Table 3 here]}

\subsection{Managerial practices supporting decentralization}

If headquarters are not heavily involved in scrutinizing the plans of organizationally distant subsidiaries, then we would also expect these subsidiaries to exhibit managerial practices that support decentralized decision-making (Hypothesis 2). Table 4 tests this idea using several additional questions from the World Management Survey (WMS).

Columns 1 and 2 focus on goal setting. We argue that, to support decentralized decision-making, goals must be clearly specified and progress toward their achievement must be measured. Column 1 shows that the extent to which goals are broken down to individual workers in a subsidiary is positively related to organizational distance from headquarters. Column 2 shows that goals are more clearly specified and measurable in lower-level subsidiaries. This supports the view that greater autonomy in organizationally 
distant subsidiaries is at least partly supported by clear goals and targets whose achievement can be measured.

Columns 3-6 focus on the relationship between internal performance reviews and organizational distance. We argue that, if headquarters are not heavily involved in monitoring organizationally distant subsidiaries, then these subsidiaries should possess effective internal control mechanisms. Consistent with this view, Column 3 shows that the extent to which measurable performance indicators are used in a subsidiary is positively related to organizational distance from headquarters. Also, performance reviews are more frequent and internal performance reviews are better structured and more consequential in organizationally distant subsidiaries (Columns 4 to 6 ).

Taken together, our results suggest that autonomy in organizationally distant subsidiaries is at least partly supported by clearly specified goals and effective internal control mechanisms.

\section{[Insert Table 4 here]}

\subsection{Responsiveness to industry growth}

Our next piece of evidence focuses on the performance implications of greater autonomy. We compare the effect of changing industry conditions on the performance of subsidiaries located at different levels in the group pyramid. The idea is that, if subsidiaries located lower down the pyramid are more autonomous from central headquarters than subsidiaries located higher up, then their response to changing industry conditions should be more similar to that of matched standalones than the response of subsidiaries located higher up (Hypothesis 3).

We focus on the relationship between the realized growth rate of a subsidiary and the aggregate industry growth rate. For each affiliate in our sample we match a comparable standalone firm. The matching is based on exact match on three-digit SIC industry code, year of incorporation and country and a continuous match on sales. Our dependent variable is the difference in 3-year growth rate between an affiliated firm and its standalone control.

Our econometric specification is as follows:

$\left(\Delta\right.$ Sales $_{i t}-\Delta$ Sales $\left._{m t}\right)=\beta_{1}$ Level $_{i}+\beta_{2}$ Level $_{i} \times \Delta$ Sales $_{j t}+\beta_{3} \Delta$ Sales $_{j t}+X_{i t}^{\prime} \beta_{5}+\eta_{g}+\varphi_{j}+c_{c}+\tau_{t}+\epsilon_{i t}$.

$\left(\Delta\right.$ Sales $_{i t}-\Delta$ Sales $\left._{m t}\right)$ is the difference in 3-year sales growth rates between a focal affiliate $i$ and its standalone control $m$. Level $i$ is $i$ 's ownership level in the group (the apex firm is at level one). $\Delta$ Sales $_{j t}$ 
is a 3-year average sales growth rate for industry $j$ (where the focal firm and the matched standalone operate). $X_{i t}$ is a vector of affiliate controls. $\eta$ is a corporate group fixed effect (that is, all estimations are within-corporate groups), $\varphi_{j}$ is a three-digit industry fixed effect, $\tau_{t}$ is year effects and $\epsilon_{i t}$ is an iid error term.

The coefficients of interest are $\beta_{2}$ and $\beta_{3}$. The winner picking view suggests that, because headquarters transfer resources from declining industries to growing industries, group membership magnifies the impact of changing industry conditions on subsidiary performance. This implies $\widehat{\beta}_{3}>0$. The co-insurance view, by contrast, suggests that headquarters tend to insulate subsidiaries from adverse industry conditions. The effect of group membership is therefore to reduce the impact of changing industry conditions on subsidiary performance. This implies $\widehat{\beta}_{3}<0$. Regardless of which effect prevails, Hypothesis 3 suggests that the magnitude of the group membership effect diminishes with organizational distance. Thus, if $\widehat{\beta}_{3}>0$, then $\widehat{\beta}_{2}<0$. If $\widehat{\beta}_{3}<0$, then $\widehat{\beta}_{2}>0$.

Table 5 presents the estimation results. We start by not controlling for matched standalone firms (Column 1). As expected, we find that changes in sales by group affiliates are strongly and positively correlated to changes in sales at the industry level. Column 2 includes matched standalone firmsthe dependent variable is now the difference in sales growth rates between an affiliate and its matched standalone firm. The coefficient estimate on the linear term of industry growth $\left(\widehat{\beta}_{3}\right)$ switches sign. Consistent with the co-insurance view, we find that $\widehat{\beta}_{3}<0$, indicating that standalone firms are, on average, more responsive to own industry conditions than group affiliates. Consistent with Hypothesis 3, this differential responsiveness depends on where the subsidiary is located in the ownership chain. The estimated interaction coefficient between ownership level and industry sales, $\widehat{\beta}_{2} \quad, \quad$ is positive and statistically significant, indicating that the relative responsiveness to external industry conditions increases with ownership level. Based on the estimates from Column 2, for subsidiaries located at level 2 (directly owned by the apex firm), a $10 \%$ increase in industry sales is associated with a $1.12 \%$ lower growth, relative to a matched standalone $(10 \% \times(-0.244+0.066 \times 2))$. This differential response to industry growth completely disappears for affiliates that are located at ownership level 4.

Columns 3 controls for joint group-industry fixed-effects to mitigate concerns that subsidiary responsiveness to external economic conditions is affected by group-industry specific effects. The results remain robust. Columns 4-6 control for equity stakes by the group's ultimate owner to mitigate the concern that the ownership level estimates are driven by the separation between ownership and control. The coefficient 
estimate on the interaction between equity stakes by the ultimate owner and industry sales growth is negative and significant, indicating that higher equity stake by the ultimate owner is associated with greater insulation of the subsidiary from external economic conditions. This is consistent with the idea that ultimate owners pay more attention to (and hence insulate more) units that are wholly-owned. The coefficient estimate on the interaction between ownership level and industry sales remains essentially unchanged. Column 5 restricts the sample to wholly-owned subsidiaries and Column 6 restricts the sample to partly-owned subsidiaries. Our results of lower insulation of affiliates from external conditions at higher ownership levels hold only for the subsample of wholly-owned affiliates. Columns 7-9 distinguish between different types of ultimate owners: family (Column 7), widely-held industrial companies (Column 8) and widely-held financial institutions (Column 9). Our result of lower insulation at higher ownership levels is driven by groups whose ultimate owners are widely-held; no such effect is found for family groups. This is consistent with the results in the next subsection indicating that family ties can mitigate the effects of organizational distance. Column 10 includes a dummy variable for the 2008-2009 great recession years to examine whether the insulation of affiliates from external conditions varies by good and bad times. Interestingly, we find that the insulation of higher level affiliates is stronger in recession years. ${ }^{9}$

\section{[Insert Table 5 here]}

\subsubsection{Moderating factors}

While organizational distance may weaken the link between headquarters and a focal subsidiary, leading to lower insulation of the subsidiary from external economic conditions, other factors may counteract this effect. For instance, if headquarters and a subsidiary are in the same industry, headquarters may devote more attention to the subsidiary and communication frictions may be lower, even if the subsidiary and headquarters are organizationally distant. Thus, we expect that subsidiary characteristics associated with

\footnotetext{
${ }^{9}$ Tax avoidance may help explain why some subsidiaries and some pyramids are created; however, it cannot easily explain our results on autonomy. For instance, how can tax avoidance explain why subsidiaries are more similar to standalone firms in terms of sales growth when organizational distance is high? Presumably groups use tax avoidance to shift paper profits from one jurisdiction to another, not to influence firm growth or any other "real" variable (Tørsløv, Wier and Zucman, 2018). Most importantly, tax avoidance considerations should not matter for domestic (same-country) groups. In unreported regressions, we re-estimated our main specifications for groups with no foreign subsidiaries. We obtain similar qualitative results for these domestic groups. For example, estimating Column 2 in Table 5 only for domestic groups $(282,338$ observations) yields a coefficient estimate on the interaction between ownership level and changes in industry sales of 0.050 (a standard error of 0.013 ), which is statistically significant at the 1 percent level. For the specifications from Column 3 in Table 5, the estimate on the interaction term between ownership level and changes in industry sales is 0.049 (a standard error of 0.013 ), which is also statistically significant at the 1 percent level. These results suggest that tax avoidance is not a plausible explanation for the greater levels of autonomy that we observe near the bottom of group pyramids.
} 
greater closeness between headquarters and the focal subsidiary will mitigate the effects of organizational distance (Hypothesis 4).

We construct six measures of closeness between headquarters and a focal subsidiary. Our closeness measures are: (i) same industry, (ii) family managers, (iii) same ethnicity, (iv) board interlocks, (v) overlap affiliate name, and (vi) same geographical region. Same industry is a dummy variable that receives the value of one for affiliates that are in the same 3-digit SIC code as the apex firms, and zero for all the other affiliates. Family managers is a dummy variable that receives the value of one for affiliates with managers that have the same last name as at least one shareholder that owns at least $5 \%$ of the total group assets, and zero for all the other affiliates. Same ethnicity is a dummy variable that receives the value of one for affiliates with a manager's ethnicity that is the same as the ethnicity of at least one manager of the apex firm, and zero for all the other affiliates. ${ }^{10}$ Board interlocks is a dummy variable that receives the value of one for affiliates with at least one board member who is also a board member of the apex firm, and zero for all the other affiliates. Overlap affiliate name is a dummy variable that receives the value of one for affiliates with a common name as the apex firm, and zero for all the other affiliates. Same geographical region is a dummy variable that receives the value of one for affiliates that are in the same 4-digit NUTS code as the apex firm, and zero for all the other affiliates.

Table 6 tests the idea that these closeness measures mitigate the effects of organizational distance. We look at how affiliates' responsiveness to industry growth (relative to matched standalone firms) varies with ownership level and each of the closeness measures. In line with Table $\mathbf{5}$, Table $\mathbf{6}$ shows that, while subsidiaries are less affected by industry growth than standalone firms, the higher their ownership level, the smaller such insulation is. The key new finding is that each of our closeness measures significantly reduces the insulation effect associated with higher ownership level. For instance, in Column 1, the reduction in insulation associated with higher ownership level is cut by about half if the subsidiary and headquarters operate in the same industry. Columns 2-6 provide similar results for the other closeness measures. Thus, overall our results provide a consistent picture. Industry and geographical proximity, as well as social relations between the group owners and subsidiary managers (as captured by family and ethnic ties), reduce the effects of organizational distance. The same is true for board interlocks and name

\footnotetext{
${ }^{10}$ To determine manager's ethnicity we use information about each manager's last name to discern the ethnic homogeneity of the top managers for each group. We quantify social diversity using the services of OriginsInfo (a subsidiary of Experian) to analyze the names of the roughly one million top managers in our dataset. OriginsInfo relies on a database that can identify the likely cultural origin of over 1,800,000 family names and 700,000 personal names. With this, we attach a unique ethnic background to each manager based on her last name.
} 
similarity. Thus, our evidence provides strong support for Hypothesis 4 .

\section{[Insert Table 6 here]}

\section{Discussion and concluding remarks}

One of the most important functions of headquarters in multidivisional organizations is to allocate resources. However, because headquarters' ability to attend to information is limited, the same level of attention cannot be devoted to all units. Attention must be allocated selectively, focusing on the most important or strategic units.

Building on the attention-based view of the firm, we argue that "organizational distance" - the number of intermediate subsidiaries separating a focal subsidiary from headquarters - is a useful proxy for how headquarters allocate their attention. The lower the organizational distance between a focal subsidiary and headquarters, the more headquarters will be involved in scrutinizing the subsidiary's plans and in providing the means necessary to accomplish these plans. By contrast, organizationally distant subsidiaries will largely operate autonomously, with little interference from the center. As a result, their performance will closely resemble that of similar standalone firms in their industry and geography. ${ }^{11}$

Using a large sample of corporate groups from 15 Western European countries, we provide three pieces of evidence consistent with these ideas. First, organizational distance is positively related to the perceived level of autonomy that subsidiary managers enjoy, as measured by the World Management Survey (Bloom and Van Reenen, 2007). Second, subsidiaries are more likely to exhibit managerial practices that support autonomy and decentralized decision-making as organizational distance increases. Third, differences in responsiveness to changing industry conditions between subsidiaries and matched standalone firms decline with organizational distance. It is obviously reassuring that organizational distance and independent survey measures of subsidiary autonomy are strongly positively correlated. What is more, the WMS measures that turn out to be the most significant in our analysis - "Share HQ managers on site" and "investment autonomy" — are also those that arguably better capture formal resource allocation mechanisms such as "closer scrutiny of [the subsidiary's] strategic plans, and [...] a higher frequency of

\footnotetext{
${ }^{11}$ We stress that, although lower-level subsidiaries may be largely insulated from headquarters' resource allocation influence, other types of coordination among subsidiaries - especially in functions such as manufacturing and marketingmay still be present. For instance, in Unilever's geographically decentralized structure, cross-regional coordination within the Hungary, Croatia and Slovenia's sub-region is delegated to Unilever Hungary (Alfordi, Clegg and McGaughey, 2012). Coordination by intermediate parents can create economies of scale and scope, thus justifying the existence of corporate group structures even when headquarters can only devote very limited attention to lower-level subsidiaries.
} 
visits", as emphasized by Ambos et al. (2010: 1103).

At a broad level, our evidence supports a key tenet of the attention-based view that "organizational architecture structurally distributes managerial attention throughout the firm, with managers within various subunits and organizational levels focusing attention on different aspects of the firm's agenda" (Joseph and Ocasio, 2012: 635). We find that organizational architecture and headquarters' allocation of attention are tightly coupled, with headquarters exerting a more important resource allocation role when subsidiaries are organizationally close.

The attentional perspective advanced in this paper differs significantly from other important perspectives on group structure in the literature. Corporate finance scholars hold that tall pyramidal structures are often created to magnify the voting power of large shareholders, possibly with an expropriative intent (Bebchuk et al., 2000; Claessens et al., 2000). In the context of large groups in Western Europe, we find little support for this view. The majority of large groups in our sample are wholly or almost wholly owned, suggesting that extending the voting power of dominant shareholders through stock pyramids cannot be the main reason for the existence of these pyramidal structures. Rather than magnifying the control of dominant shareholders, tall pyramids appear to structurally distribute and attenuate headquarters attention.

Other scholars tend to ignore the legal structure of multinational groups, as reflected by parentsubsidiary chains. Stopford and Wells (1972: 10), for instance, argue that "the legal structure [of multinational enterprises] can be ignored [...] [T]he legal structure is designed, in accordance with government regulations, for cash-flow and tax purposes; it seldom reflects the way in which the enterprise is managed". While we agree that legal structure is often designed in accordance with government regulations, or for tax or limited liability purposes, we also show that organizational structure is systematically related to how headquarters attention is allocated. This information is likely to be valuable, not least because data on parent-subsidiary chains is typically much more readily available than data on managerial attention patterns.

Our results have implications for debates about the nature and functions of corporate groups in society, as well as the theory of the firm more generally. In reviewing the growing literature on corporate groups, Khanna and Yafeh (2007) warn that the link between corporate groups and the expropriation of minority shareholders is becoming an unquestioned axiom, which they believe is unwarranted. Khanna and Yafeh urge researchers to document how many groups around the world are actually vertically con- 
trolled pyramids and where they are located. Our work is a step in that direction. In many cases, we argue, tall pyramids are not an indicator of expropriative intent, but of decentralized decision-making. A "Chandlerian" perspective, where groups grow over time to exploit diversification opportunities and select legal forms fitting their institutional context, is in our view a more plausible explanation for the existence of corporate groups in many contexts. This does not mean that expropriation of minority shareholders is not sometimes an important concern, especially in developing countries where investor protection is weak.

Our study provides evidence on the nature of resource allocation in groups. We show that, at least in Western Europe and in a period characterized by great turbulence (the financial crisis of 2008-2009 and its aftermath), headquarters are more likely to support or 'prop up' affiliates in declining segments than to support affiliates in growing segments. Our findings suggest that group affiliates will perform comparatively better when conditions in their industry are bad (because they receive support from the group) and perform comparatively worse when conditions in their industry are good (because they provide support to other affiliates).

It is not clear a priori whether co-insurance is a source of competitive advantage or disadvantage at the group level. Some scholars view co-insurance in a negative way, as the outcome of influence activities or misguided concerns for equality (a form of 'corporate socialism'). However, co-insurance can also reduce the risk of bankruptcy and facilitate access to credit (Lewellen, 1971; Byun et al., 2013). Examining the performance implications of co-insurance at the group level is a very interesting avenue for future research.

We stress again that, while we document a robust correlation between organizational distance and subsidiary autonomy, this does not imply that a causal relationship exist. Communication and governance frictions may hinder headquarters' control, especially when subsidiaries are organizationally distant, but factors such as lack of headquarters' interest may be correlated both with organizational distance and subsidiary autonomy. For instance, headquarters may only directly acquire subsidiaries that they deem strategically important (and to which they intend to devote a lot of attention), while delegating the acquisition of less strategic subsidiaries to lower-level parents. Of course, both mechanisms may be at work, with communication and governance frictions hindering headquarters' control, and headquarters, because of this, choosing to directly own only the most important or strategic units.

Another limitation of the paper is that we can only observe incorporated subsidiaries. It would be very interesting to compare how the allocation of attention and decision making authority is distributed 
between the internal units of a single firm, as opposed to the incorporated subsidiaries of a group. A key hypothesis to be tested is that the legal incorporation of subsidiaries grants additional autonomy to units and hence is associated with lower vertical interaction.

To conclude, this paper provides a detailed analysis of the internal structure of an important economic organization, the corporate group. By emphasizing organizational architecture as a way to selectively distribute managerial attention, this paper provides a novel perspective on group structure that significantly deviates from existing perspectives focusing on magnification of control. In so doing, it develops a more positive view of tall pyramidal structures and demonstrates the usefulness of a theoretically plural approach to organization design.

Acknowledgements. We thank the editor, Alfonso Gambardella, and two anonymous referees for very constructive comments and suggestions that greatly improved the paper. We also thank participants at several seminars and conferences for helpful suggestions. All remaining errors are of course our own.

\section{References}

[1] Alfordi EA, Clegg LJ, McGaughey SL. 2012. Coordination at the edge of the empire: The delegation of headquarters functions through regional management mandates. Journal of International Management 18(3): 276-292.

[2] Almeida H, Wolfenzon D. 2006. A theory of pyramidal ownership and family business groups. Journal of Finance 61(6): 2637-2680.

[3] Alonso R, Dessein W, Matouschek N. 2008. When does coordination require centralization? American Economic Review 98(1): 145-179.

[4] Ambos T.C., Andersson, U., Birkinshaw, J. 2010. What are the consequences of initiative taking in multinational subsidiaries. Journal of International Business Studies 41(7): 1099-1118.

[5] Anand J, Singh H. 1997. Asset redeployment, acquisitions and corporate strategy in declining industries. Strategic Management Journal 18(S1): 99-118.

[6] Andersson U, Forsgren M, Holm U. 2002. The strategic impact of external networks: Subsidiary performance and competence development in the multinational corporation. Strategic Management Journal 23(11): 979-996.

[7] Ayotte K, Hansmann H. 2012. Legal entities as transferable bundles of contracts. Michigan Law Review 111: 715-758.

[8] Bartlett CA, Ghoshal S. 1989. Managing Across Borders. The Transnational Solution. Harvard Business School Press: Boston, MA.

[9] Baysinger B, Hoskisson RE. 1990. The composition of boards of directors and strategic control: Effects on corporate strategy. Academy of Management Review 15(1): 72-87. 
[10] Bebchuk LA, Kraakman R, Triantis G. 2000. Stock pyramids, cross-ownership and dual class equity: The mechanisms and agency costs of separating control from cash-flow rights. In R. Morck (Ed.), Concentrated Corporate Ownership, 445-460, The University of Chicago Press, Chicago.

[11] Belenzon S, Berkovitz T. 2010. Innovation in business groups. Management Science 56(3): 519-535.

[12] Belenzon S, Berkovitz T, Rios L. 2013. Capital markets and firm organization: How financial development shapes European corporate groups. Management Science 59(6): 1326-1343.

[13] Belenzon S, Lee H, Patacconi A. 2018. Towards a legal view of the firm: The effects of group liability on asset partitioning, decentralization and corporate group growth. NBER Working Paper 24720.

[14] Bertrand M, Mullainathan S. 2003. Enjoying the quiet life? Corporate governance and managerial preferences. Journal of Political Economy 111(5): 1043-1075.

[15] Bethel JE, Liebeskind J. 1998. Diversification and the legal organization of the firm. Organization Science 9(1): 49-67.

[16] Birkinshaw JM. 1996. How multinational subsidiary mandates are gained and lost. Journal of International Business Studies 27(3): 467-495.

[17] Birkinshaw JM. 1997. Entrepreneurship in multinational corporations: The characteristics of subsidiary initiatives. Strategic Management Journal 18(2): 207-230.

[18] Birkinshaw J, Braunerhjelm P, Holm U, Terjesen S. 2006. Why do some multinational corporations relocate their headquarters overseas? Strategic Management Journal 27(7): 681-700.

[19] Birkinshaw JM, Morrison AJ. 1995. Configurations of strategy and structure in subsidiaries of multinational corporations. Journal of International Business Studies 26(4): 729-753.

[20] Birkinshaw JM, Hood N, Jonsson S. 1998. Building firm-specific advantages in multinational corporations: The role of subsidiary initiative. Strategic Management Journal 19(3): 221-242.

[21] Bloom N, Van Reenen, J. 2007. Measuring and explaining management practices across firms and countries. Quarterly Journal of Economics 122(4): 1351-1408.

[22] Bloom N, Sadun R, Van Reenen J. 2012. The organization of firms across countries. Quarterly Journal of Economics 127(4): 1663-1705.

[23] Bouquet C, Birkinshaw J. 2008. Weight versus voice: How foreign subsidiaries gain attention from corporate headquarters. Academy of Management Journal 51(3): 577-601.

[24] Bouquet C, Morrison A, Birkinshaw J. 2009. International attention and multinational enterprise performance. Journal of International Business Studies 40(1): 108-131.

[25] Bower JL. 1970. Managing the Resource Allocation Process. Harvard Business School Press, Boston, MA.

[26] Byun HY, Choi S, Hwang LS, Kim RG. 2013. Business group affiliation, ownership structure, and the cost of debt. Journal of Corporate Finance 23: 311-331.

[27] Chandler AD. 1962. Strategy and Structure: Chapters in the History of the American Industrial Enterprise. Cambridge, MA: MIT.

[28] Chandler AD. 1991. The functions of the HQ unit in the multibusiness firm. Strategic Management Journal 12(S2): 31-50. 
[29] Chang SJ, Choi U. 1988. Strategy, structure and performance of Korean business groups: A transactions cost approach. Journal of Industrial Economics 37(2): 141-158.

[30] Chang SJ, Hong J. 2000. Economic performance of group-affiliated companies in Korea: Intragroup resource sharing and internal business transactions. Academy of Management Journal 43(3): 429448.

[31] Claessens S, Djankov S, Lang L, 2000. The separation of ownership and control in East Asian corporations. Journal of Financial Economics 58(1): 81-112.

[32] Collis D, Young D, Goold M. 2007. The size, structure, and performance of corporate headquarters. Strategic Management Journal 28(4): 383-405.

[33] Dessein W. 2002. Authority and communication in organizations. Review of Economic Studies 69(4): 811-838.

[34] Economist. (2016, October 6). In formation. Europe's big planemaker takes another short hop towards being a "normal" firm. Economist.

[35] Ethiraj SK, Levinthal D. 2004a. Modularity and innovation in complex systems. Management Science 50(2): 159-173.

[36] Ethiraj SK, Levinthal D. 2004b. Bounded rationality and the search for organizational architecture: An evolutionary perspective on the design of organizations and their evolvability. Administrative Science Quarterly 49(3): 404-437.

[37] Ferris SP, Kim KA, Kitsabunnarat P. 2003. The costs (and benefits?) of diversified business groups: The case of Korean chaebols. Journal of Banking 86 Finance 27(2): 251-273.

[38] Freeland RF. 1996. The myth of the M-form? Governance, consent, and organizational change. American Journal of Sociology 102(2): 483-526.

[39] Galbraith JR. 1973. Designing Complex Organizations. Addison-Wesley.

[40] Garicano L. 2000. Hierarchies and the organization of knowledge in production. Journal of Political Economy 108(5): 874-904.

[41] Goold M, Campbell A. 2002. Parenting in complex structures. Long Range Planning 35(3): 219-243.

[42] Ghoshal S, Bartlett CA. 1990. The multinational corporation as an interorganizational network. Academy of Management Review 15(4): 603-626.

[43] Ghoshal S, Nohria N. 1989. Internal differentiation within multinational corporations. Strategic Management Journal 10(4): 323-337.

[44] Gupta AK, Govindarajan V. 1991. Knowledge flows and the structure of control within multinational corporation. Academy of Management Review 16(4): 768-792.

[45] Harris M, Raviv A. 1996. The capital budgeting process: Incentives and information. Journal of Finance 51(4): 1139-1174.

[46] Hoskisson RE, Hitt MA, Hill CW. 1993. Managerial incentives and investment in R\&D in large multiproduct firms. Organization Science 4(2): 325-341.

[47] Johnson S, La Porta R, Lopez-de Silanes F, Shleifer A. 2000. Tunneling. American Economic Review 90(2): 22-27. 
[48] Joseph J, Ocasio W. 2012. Architecture, attention, and adaptation in the multibusiness firm: General Electric from 1951 to 2001. Strategic Management Journal 33(6): 633-660.

[49] Joseph J, Wilson AJ. 2018. The growth of the firm: An attention-based view. Strategic Management Journal 39(6): 1779-1800.

[50] Kandel E, Kosenko K, Morck R, Yafeh Y. 2013. The great pyramids of America: A revised history of US business groups, corporate ownership and regulation, 1930-1950. NBER Working Paper 19691.

[51] Khanna T, Yafeh Y. 2005. Corporate groups and risk sharing around the world. Journal of Business 78(1): 301-340.

[52] Khanna T, Yafeh Y. 2007. Corporate groups in emerging markets: Paragons or parasites? Journal of Economic Literature 45: 331-372.

[53] La Porta R, Shleifer A, Lopez de Silanes F. 1999. Corporate ownership around the world. Journal of Finance 54(2): 471-517.

[54] Lawrence PR, Lorsch JW. 1967. Differentiation and integration in complex organizations. Administrative Science Quarterly 12(1): 1-47.

[55] Leff NH. 1978. Industrial organization and entrepreneurship in the developing countries: The economic groups. Economic Development and Cultural Change 26: 661-675.

[56] Lewellen WG. 1971. A pure financial rationale for the conglomerate merger wave. Journal of Finance 26(2): $521-537$.

[57] March JG, Simon HA. 1958. Organizations. Cambridge, MA: Blackwell.

[58] Martinez JI, Jarillo JC. 1989. The evolution of research on coordination mechanisms in multinational corporations. Journal of International Business Studies 20(3): 489-514.

[59] Meyer M, Milgrom P, Roberts J. 1992. Organizational prospects, influence costs, and ownership changes. Journal of Economics 83 Management Strategy 1(1): 9-35.

[60] Milgrom P, Roberts J. 1988. An economic approach to influence activities in organizations. American Journal of Sociology 94: S154-S179.

[61] Morck R, Wolfenzon D, Yeung B. 2005. Corporate governance, economic entrenchment, and growth. Journal of Economic Literature 43(3): 655-720.

[62] Mudambi R, Navarra P. 2004. Is knowledge power? Knowledge flows, subsidiary power and rentseeking within MNCs. Journal of International Business Studies 35(5): 385-406.

[63] New York Times. (2015, August 11). Google Goal in Restructuring as Alphabet: Autonomy. By Conor Dougherty. Available at https://www.nytimes.com/2015/08/12/technology/autonomy-seenas-goal-of-restructured-google.html

[64] Ocasio W. 1997. Towards an attention-based view of the firm. Strategic Management Journal 18(Summer Special Issue): 187-206.

[65] Ozbas O. 2005. Integration, organizational processes, and allocation of resources. Journal of Financial Economics 75(1): 201-242.

[66] Patacconi A. 2009. Coordination and delay in hierarchies. RAND Journal of Economics 40(1): 190208. 
[67] Piekkari R, Nell PC, Ghauri PN. 2010. Regional management as a system. Management International Review 50(4): 513-532.

[68] Prahalad CK, Bettis RA. 1986. The dominant logic: A new linkage between diversity and performance. Strategic Management Journal 7(6): 485-501.

[69] Prahalad CK, Hamel G. 1990. The core competence of the corporation. Harvard Business Review 68(3): 79-91.

[70] Schoar A. 2002. Effects of corporate diversification on productivity. Journal of Finance 57(6): 23792403.

[71] Simon HA. 1947. Administrative Behavior: A Study of Decision making Processes in Administrative Organization. New York: The Macmillan Company.

[72] Simon HA. 1962. The architecture of complexity. Proceedings of the American Philosophical Society 106(2): 467-482.

[73] Stan M, Puranam P. 2017. Organizational adaptation to interdependence shifts: The role of integrator structures. Strategic Management Journal 38(5): 1041-1061.

[74] Stein JC. 1997. Internal capital markets and the competition for corporate resources. Journal of Finance 52(1): 111-133.

[75] Stopford JM, Wells LT. 1972. Managing the Multinational Enterprise: Organization of the Firm and Ownership of the Subsidiary. Basic Books: New York.

[76] Teece DJ. 1980. Economies of scope and the scope of the enterprise. Journal of Economic Behavior \& Organization 1(3): 223-247.

[77] Tørsløv TR, Wier LS, Zucman G. 2018., The missing profits of nations. NBER Working Paper 24701.

[78] Williamson OE. 1975. Markets and Hierarchies. Analysis and Antitrust Implications.

[79] Williamson OE. 1981. The modern corporation: Origins, evolution, attributes. Journal of Economic Literature 19(4): 1537-1568.

[80] Williamson OE. 1991. Strategizing, economizing, and economic organization. Strategic Management Journal 12(S2): 75-94. 


\section{Figure 1a. Distribution of Group Assets by Corporate Group Depth}

\section{Distribution of Group Assets}

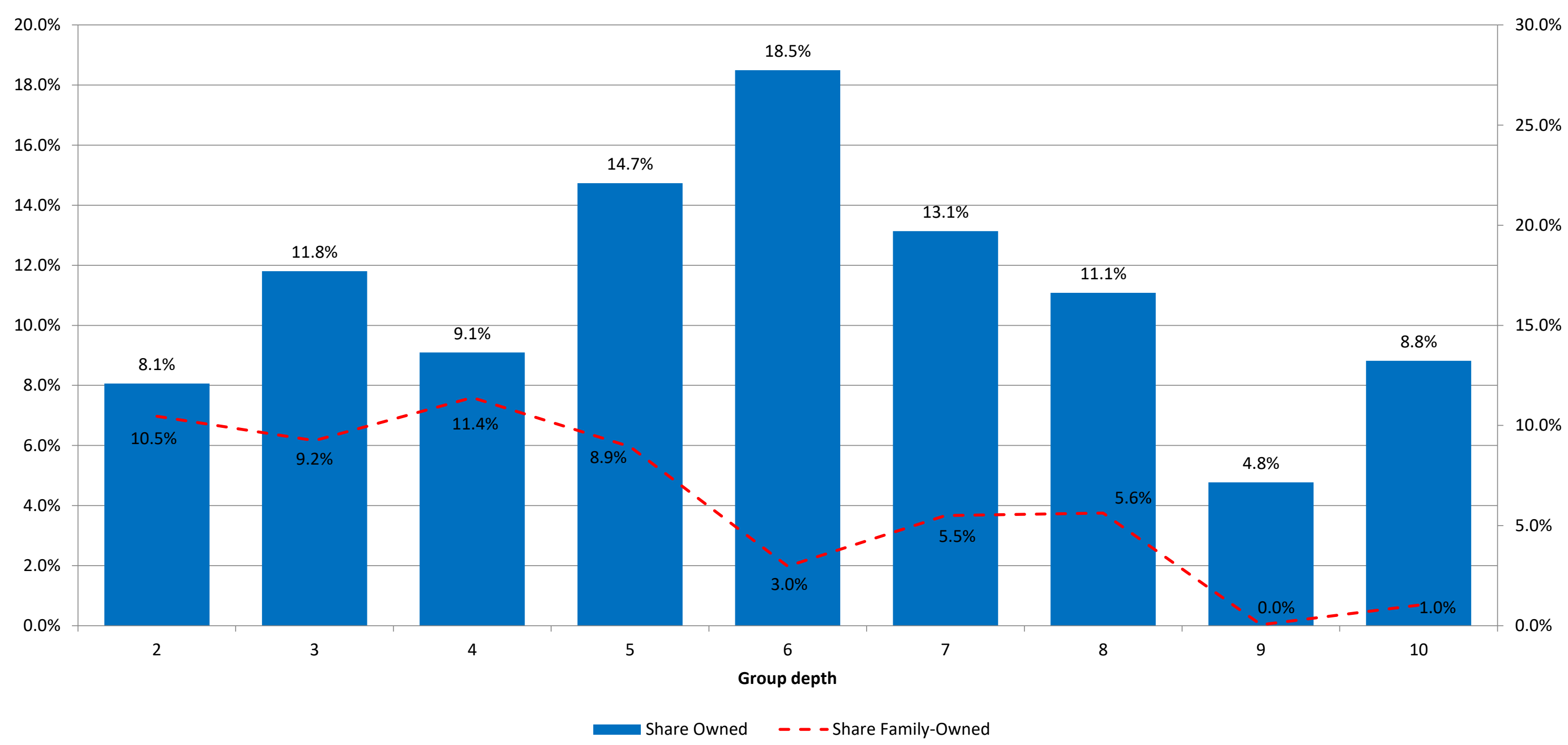

Note: This figure presents the distribution of group assets in our sample by corporate group depth. Corporate group depth is defined as the maximum ownership level of the subsidiaries of a group. The bars represent the share of assets controlled by groups in Europe with different maximum ownership levels. The red dotted line represents assets controlled by family-owned corporate groups as a percentage of the total assets controlled within each level. Level 10 aggregates maximum levels of 10 and greater. 


\section{Figure 1b. Distribution of Group Assets by Corporate Group Depth across Countries}
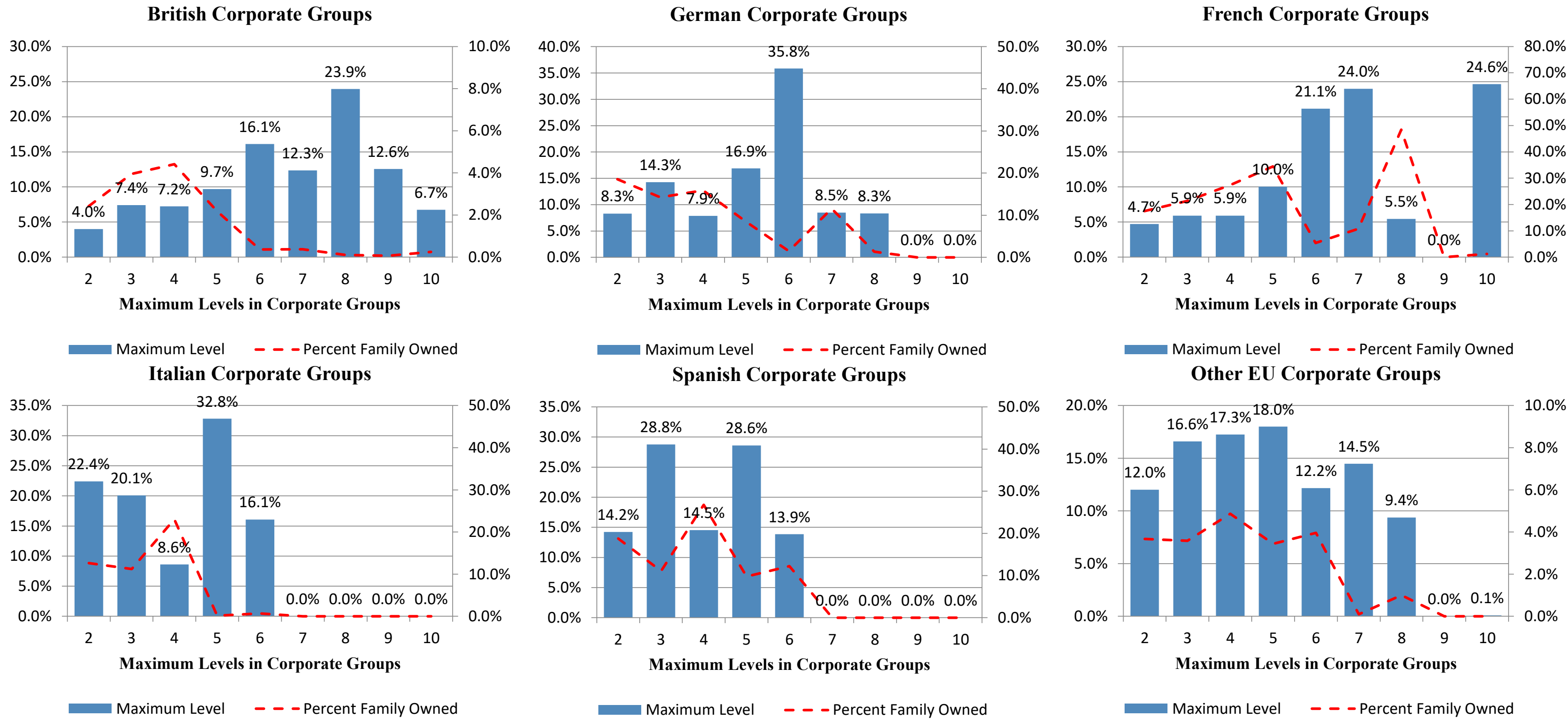

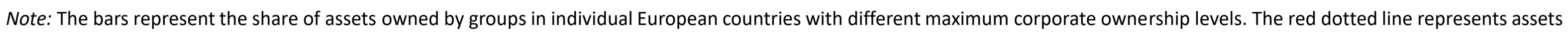
controlled by family-owned corporate groups as a percent of the total assets controlled within each level (level 10 aggregates maximum levels of 10 and greater). 


\section{Figure 2. Cumulative Distribution of Assets Within Groups of Same Depth by Ownership Level}

$\%$ Cumulative Assets GD $=2$

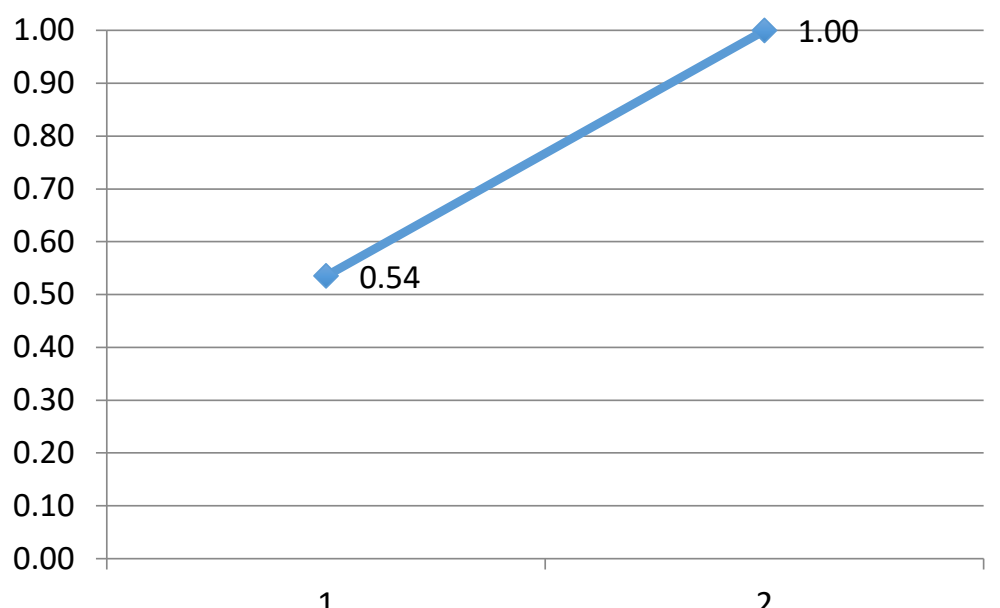

Corporate Group Levels

\% Cumulative Assets GD $=5$

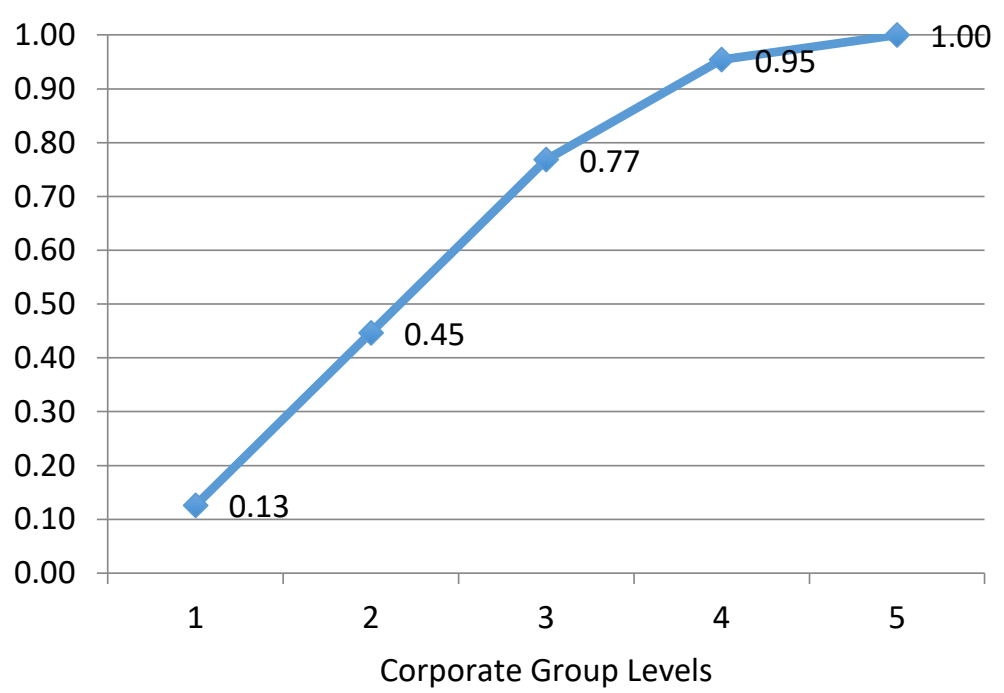

\% Cumulative Assets GD = 3

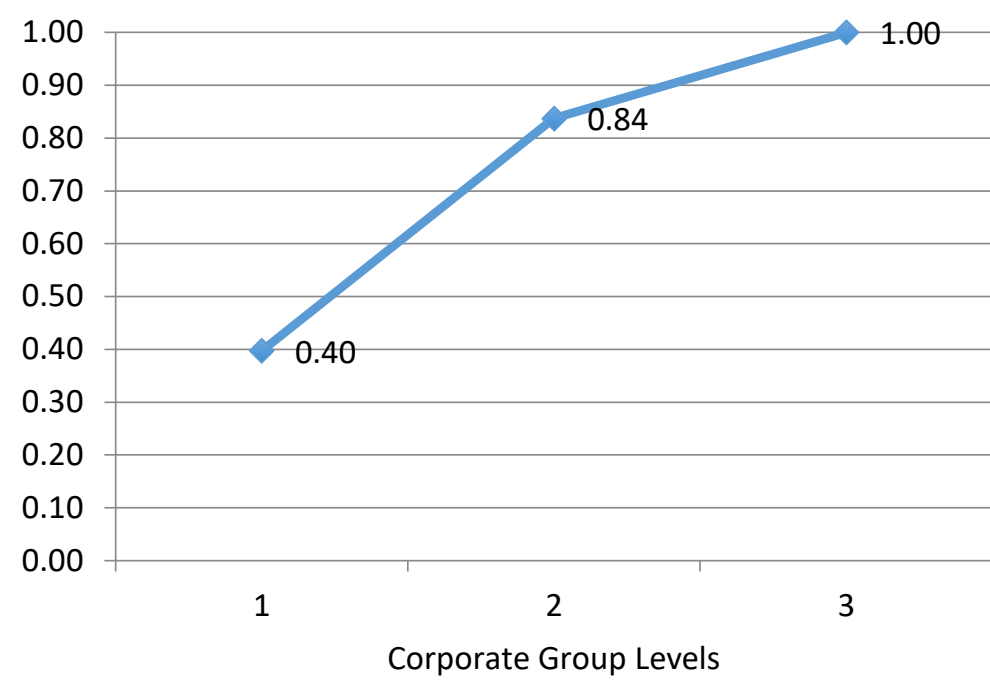

\% Cumulative Assets GD $=6$

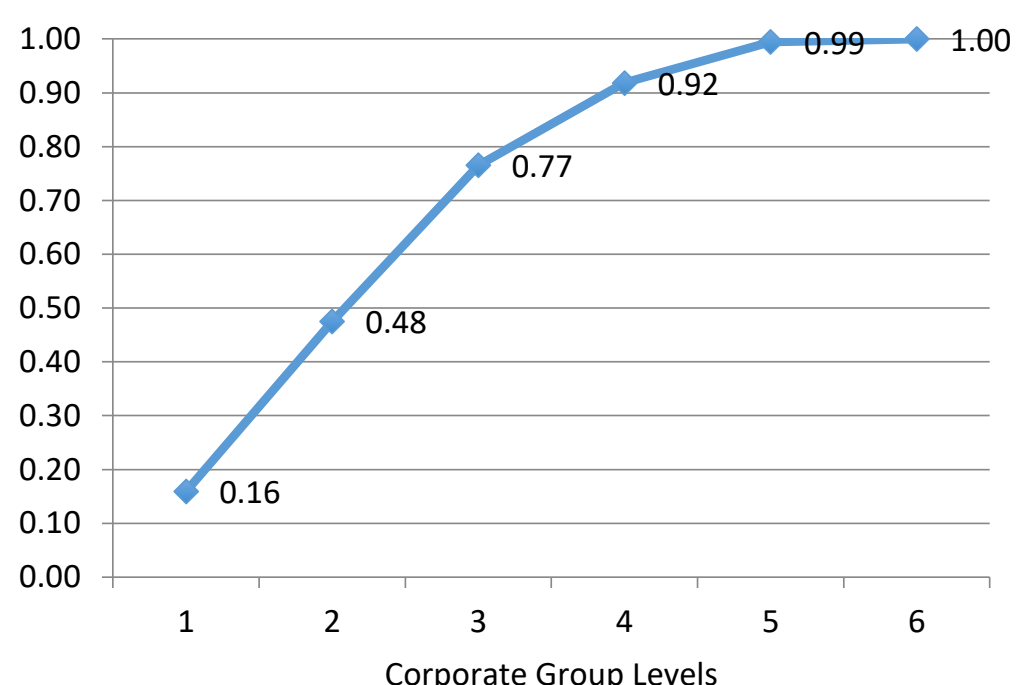

$\%$ Cumulative Assets GD $=4$

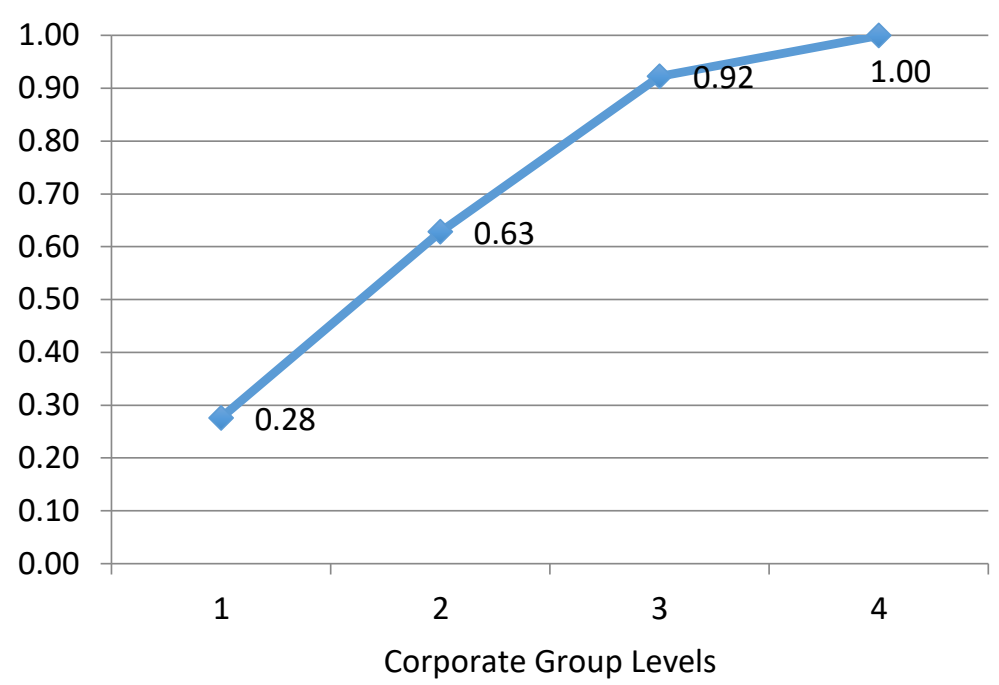

\% Cumulative Assets GD = 7

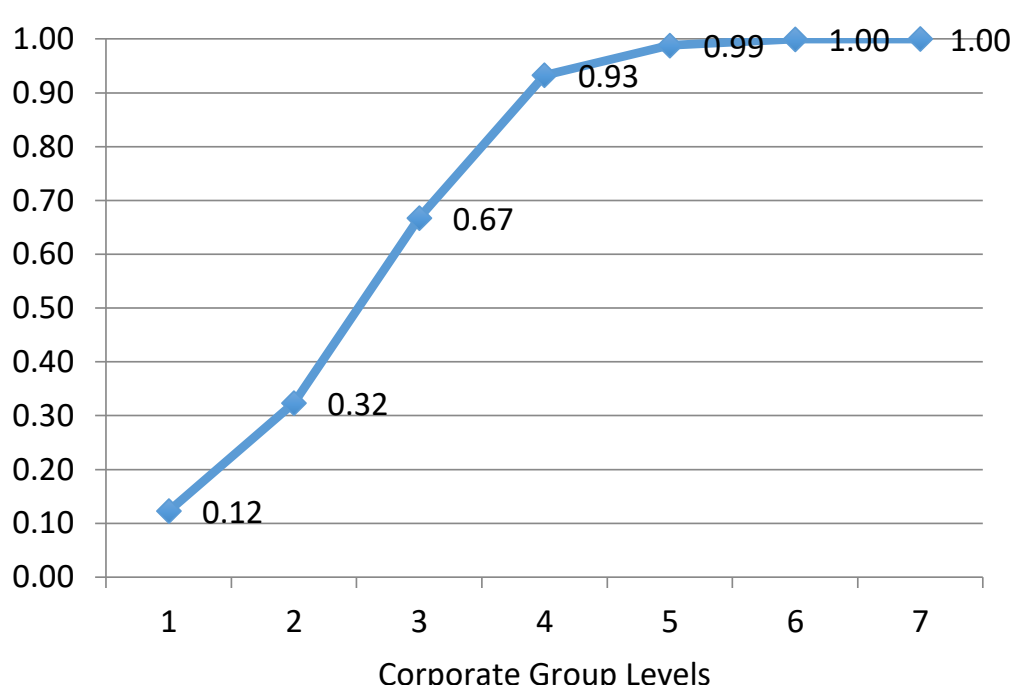

Note: The figures present the cumulative distribution of assets across levels among groups with the same group depth, GD. For example, for corporate groups with three levels (GD $=3$ ), the first level holds on average $40 \%$ of the total assets, the second level holds on average $44 \%$ of the totals assets, and the third level holds on average $16 \%$ of the total assets. 


\section{Figure 3. Wholly-Owned Groups by Country and Ultimate Owner Type}
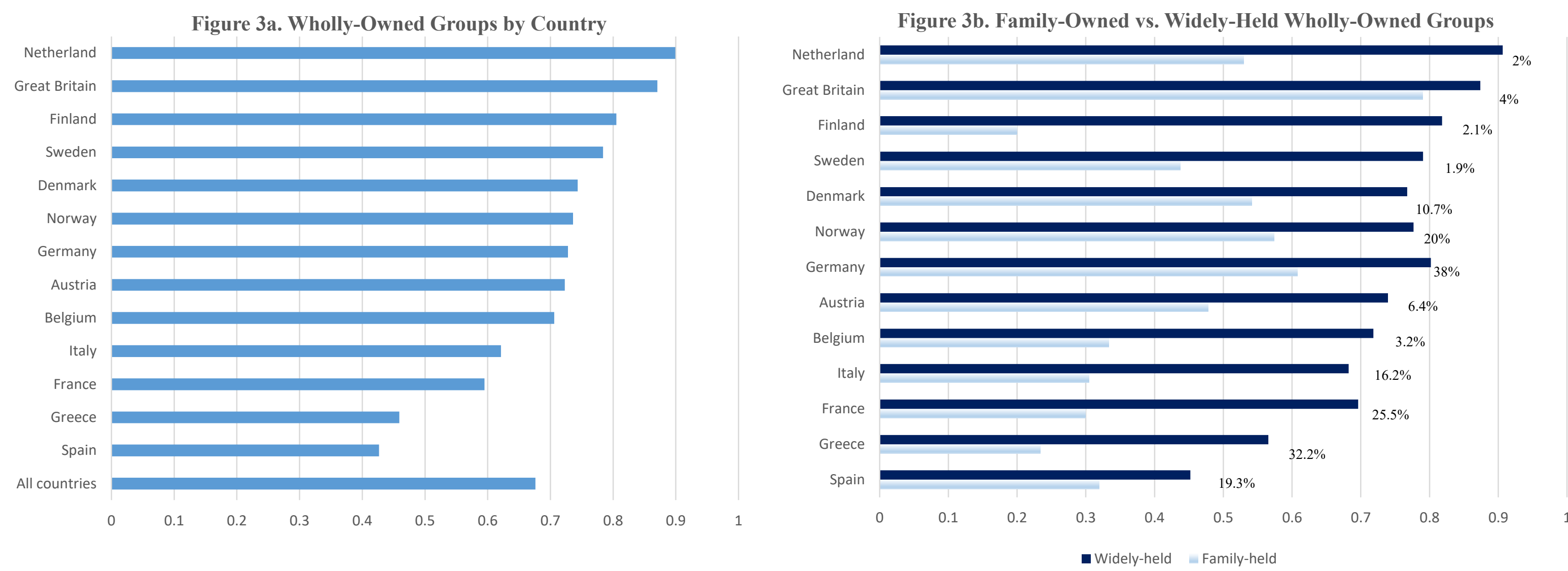

Note: Figure 3 presents the distribution of wholly-owned groups by country (Figure 3a) and for family-owned vs. widely-held groups (Figure 3b). A corporate group is classified as wholly-owned if the ultimate owner of the group owns on average at least $95 \%$ of the group affiliates' equity. In Figure $3 b$, the \% values are the percentage of family-held groups in each country. Only groups that generate at least $\$ 100 \mathrm{~m}$ in annual sales are included in this sample. 
Figure 4a. Subsidiary ownership level and ultimate owner equity stakes.

Subsidiary ownership level and equity stakes by country

0.95

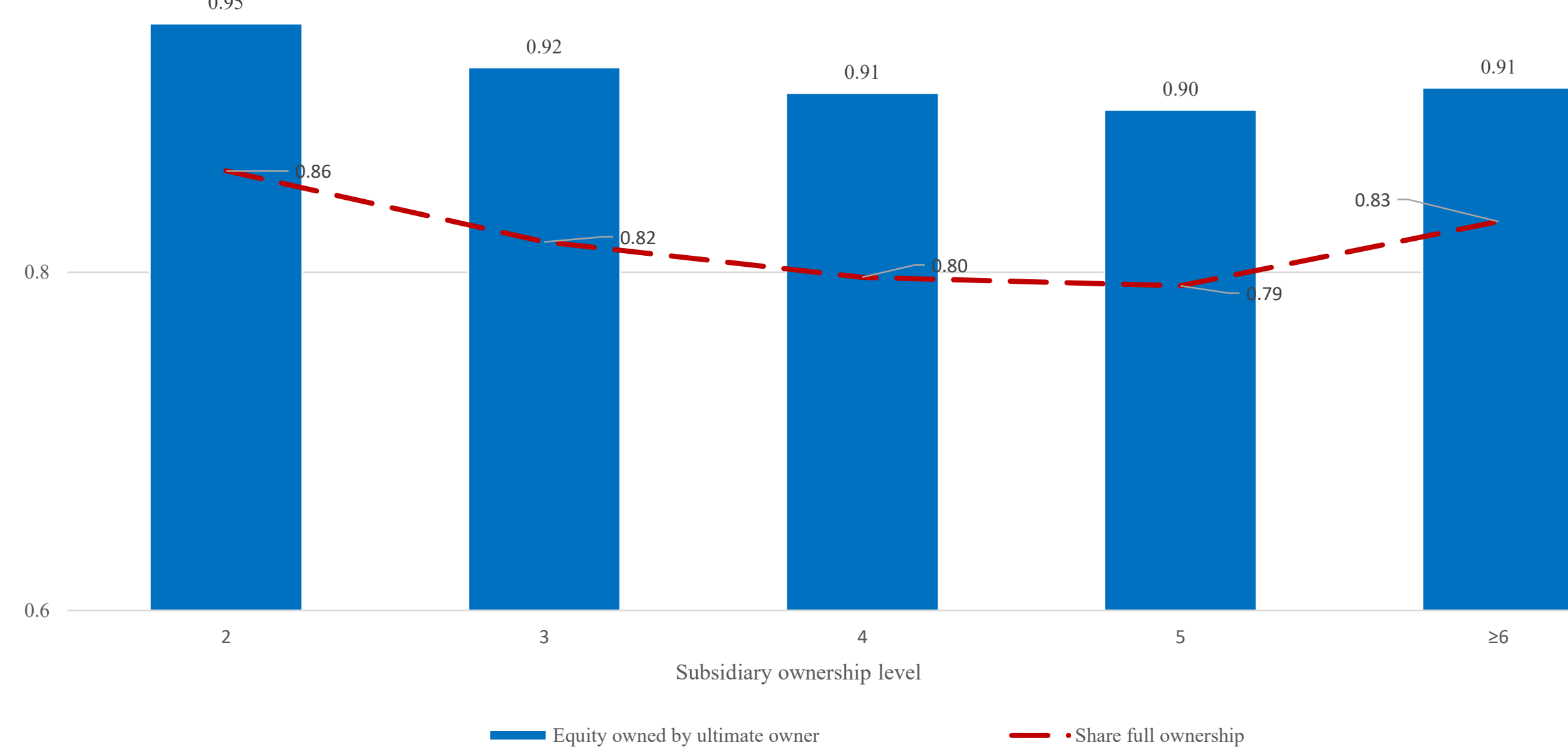

Note: This figure presents the share of equity held by the corporate group's ultimate owner by ownership level. The bars plot the share of equity and the dashed line plots the share of ownership links that are wholly-owned (100\%). For example, for affiliates of ownership level 2 (one level below the apex firm), the apex firm holds on average $95 \%$ of equity and $86 \%$ of equity ties are wholly-owned. 
Table 1. Summary Statistics

\begin{tabular}{lcccccc}
\hline \hline & & & & \multicolumn{3}{c}{ Distribution } \\
\cline { 5 - 8 } Variable & \# firms & Mean & Std. Dev. & 10st & 50th & 90th \\
\hline 3-year Sales Growth & 707,159 & 0.409 & 0.855 & -0.538 & 0.218 & 0.697 \\
Sales t'-3 $\left.^{\prime} 000, \$\right)$ & 719,591 & 96,455 & $1,541,163$ & 217 & 4,860 & 87,833 \\
Number of Employees & 460,489 & 434 & 5,497 & 3 & 36 & 415 \\
Total Assets ('000, \$) & 719,591 & 222,686 & $6,972,096$ & 484 & 5,907 & 106,355 \\
Return on Assets (EBIT/Assets) & 719,591 & 0.032 & 0.264 & -0.088 & 0.030 & 0.188 \\
Year of Incorporation & 645,192 & 1986 & 27.1 & 1963 & 1991 & 2002 \\
Number of Group Affiliates & 719,591 & 40.2 & 114.8 & 3 & 7 & 85 \\
Group Sales ('000, \$) & 719,591 & $4,932,688$ & $26,248,940$ & 2,811 & 70,092 & $4,362,589$ \\
\hline
\end{tabular}

Notes: Financial information covers the period 2006-2010. Ownership is based on 2006 data.

Table 2. Subsidiary Characteristics by Ownership Level

\begin{tabular}{|c|c|c|c|c|c|c|c|c|c|}
\hline & $(1)$ & $(2)$ & $(3)$ & $(4)$ & $(5)$ & $(6)$ & $(7)$ & $(8)$ & $(9)$ \\
\hline & $\begin{array}{c}\text { 3-year } \\
\text { sales } \\
\text { growth }\end{array}$ & $\begin{array}{c}\text { Sales } \\
\left(\$,{ }^{\prime} 000\right) \\
\end{array}$ & $\begin{array}{l}\text { Assets } \\
\left(\$,{ }^{\prime} 000\right)\end{array}$ & Employess & $\begin{array}{c}\text { Return on } \\
\text { assets }\end{array}$ & $\begin{array}{c}\text { Cash flow } \\
(\$, ' 000)\end{array}$ & $\begin{array}{c}\% \% \\
\text { Publicly } \\
\text { traded }\end{array}$ & $\begin{array}{c}\% \text { Wholly- } \\
\text { owned }\end{array}$ & $\begin{array}{l}\text { Direct } \\
\text { equity } \\
\text { stakes } \\
\end{array}$ \\
\hline \multicolumn{10}{|l|}{ Ownership level: } \\
\hline $1^{s t}$ (Apex) & 0.467 & 90,944 & 418,514 & 337 & 0.044 & 9,128 & 4.46 & & - \\
\hline $2^{\text {nd }}$ & 0.396 & 45,445 & 124,977 & 122 & 0.027 & 3,678 & 0.61 & 0.95 & 0.86 \\
\hline $3^{r d}$ & 0.393 & 67,473 & 77,267 & 167 & 0.025 & 5,663 & 0.29 & 0.92 & 0.82 \\
\hline $4^{\text {th }}$ & 0.416 & 100,324 & 103,677 & 224 & 0.030 & 8,579 & 0.26 & 0.91 & 0.80 \\
\hline $5^{\text {th }}$ & 0.405 & 95,537 & 121,514 & 261 & 0.023 & 8,644 & 0.07 & 0.90 & 0.79 \\
\hline $6^{\text {th }}$ and above & 0.377 & 79,748 & 135,070 & 261 & 0.046 & 8,251 & 0.00 & 0.91 & 0.83 \\
\hline Wholly-Owned Subsidiaries & 0.414 & 111,921 & 235,784 & 365 & 0.031 & 11,845 & - & - & - \\
\hline Partly-Owned Subsidiaries & 0.390 & 79,038 & 92,429 & 226 & 0.025 & 7,075 & 0.74 & - & 0.615 \\
\hline
\end{tabular}

Notes: Financial information covers the period 2006-2010. Ownership is based on 2006 data. 
Table 3. Perceived Autonomy by Subsidiary Managers and Ownership Level

\begin{tabular}{|c|c|c|c|c|c|c|c|}
\hline & (1) & (2) & (3) & (4) & (5) & (6) & (7) \\
\hline & Hierarchy & Share HQ & & & & Sales and & New \\
\hline & Levels to & Managers & Autonomy & Hiring & $\ln$ (Investment & Marketing & Product \\
\hline WMS survey measure: & $\mathrm{CEO}$ & On Site & Score & Autonomy & Autonomy) & Autonomy & Introduction \\
\hline \multirow[t]{2}{*}{$\ln$ (Ownership Level) } & 0.503 & -0.152 & 0.203 & 0.248 & 0.763 & 0.242 & 0.092 \\
\hline & $(0.124)$ & $(0.043)$ & $(0.105)$ & $(0.137)$ & $(0.205)$ & $(0.153)$ & $(0.147)$ \\
\hline \multirow[t]{2}{*}{ Equity Stakes by Ultimate Owner } & 0.411 & -0.083 & 0.108 & 0.208 & 0.557 & -0.089 & 0.070 \\
\hline & $(0.217)$ & $(0.077)$ & $(0.168)$ & $(0.220)$ & $(0.465)$ & $(0.238)$ & $(0.221)$ \\
\hline \multirow[t]{2}{*}{ ln(Firm Employees) } & 0.305 & -0.072 & 0.006 & 0.091 & 0.142 & 0.011 & -0.009 \\
\hline & $(0.035)$ & $(0.013)$ & $(0.029)$ & $(0.036)$ & $(0.060)$ & $(0.041)$ & $(0.038)$ \\
\hline \multirow[t]{2}{*}{ Firm Age } & 0.006 & 0.019 & -0.118 & -0.225 & 0.023 & -0.042 & -0.003 \\
\hline & $(0.072)$ & $(0.026)$ & $(0.061)$ & $(0.084)$ & $(0.134)$ & $(0.093)$ & $(0.085)$ \\
\hline \multirow[t]{2}{*}{$\ln$ (Number of Group Affiliates) } & 0.049 & -0.030 & -0.004 & -0.079 & 0.042 & 0.042 & 0.029 \\
\hline & $(0.026)$ & $(0.009)$ & $(0.023)$ & $(0.029)$ & $(0.050)$ & $(0.033)$ & $(0.031)$ \\
\hline Country Dummies (7) & Yes & Yes & Yes & Yes & Yes & Yes & Yes \\
\hline Two-digit Industry Dummies (19) & Yes & Yes & Yes & Yes & Yes & Yes & Yes \\
\hline Avg. Survey Value: & 3.56 & 0.70 & 2.72 & 3.21 & 54,821 & 2.31 & 2.49 \\
\hline Avg. Ownership Level: & 3.20 & 3.21 & 3.21 & 3.21 & 3.21 & 3.21 & 3.21 \\
\hline Std. Ownership Level: & 1.18 & 1.18 & 1.18 & 1.18 & 1.14 & 3.19 & 3.19 \\
\hline Observations & 1,173 & 1,361 & 1,305 & 1,415 & 985 & 1,189 & 1,152 \\
\hline R-squared & 0.150 & 0.173 & 0.038 & 0.048 & 0.107 & 0.051 & 0.032 \\
\hline
\end{tabular}

Notes: This table examines the relationship between the perceived autonomy of subsidiary managers, as measured by the World Management Survey (WMS), and organizational distance. Hierarchy levels to CEO (Column 1) is the number of hierarchical levels that separate a subsidiary manager from headquarters (WMS label: level2ceo, "Number of levels in the firms between the shopfloor and the CEO "). Share HQ managers on site (Column 2) is the percentage of headquarters managers that are at the subsidiary site (WMS label: onsite, "Is CHQ on the site being interviewed?"). Column 3 is the aggregate survey response to the autonomy questions, with higher values indicating greater subsidiary autonomy (WMS label: central). The disaggregated autonomy questions are presented in Columns 5-7, as follows. Column 4: "To hire a fulltime permanent shop floor worker what agreement would your plant need from CHQ?". Column 5: What is the largest capital investment your plant could make without prior authorization from CHQ?" Column 6: "How much of sales and marketing is carried out at the plant level (rather than at the CHQ)?" Column 7: "Where are decisions taken on new product introductions - at the plant, at the CHQ or both?" Robust standard errors in parentheses. 
Table 4. Managerial Practices Supporting Decentralization and Ownership Level

\begin{tabular}{|c|c|c|c|c|c|c|}
\hline & (1) & (2) & (3) & (4) & (5) & (6) \\
\hline & \multicolumn{2}{|c|}{ A. Goal Setting } & \multicolumn{4}{|c|}{ B. Performance Review } \\
\hline WMS survey measure: & $\begin{array}{c}\text { Extent of goal } \\
\text { breakdown }\end{array}$ & $\begin{array}{c}\text { Goal clarity } \\
\& \\
\text { mesaurement }\end{array}$ & $\begin{array}{c}\text { Measurable } \\
\text { performance } \\
\text { indicators }\end{array}$ & $\begin{array}{c}\text { Frequency of } \\
\text { performance } \\
\text { review }\end{array}$ & $\begin{array}{c}\text { Strucutred } \\
\text { performance } \\
\text { review }\end{array}$ & $\begin{array}{l}\text { Achievement } \\
\text { of objectives } \\
\text { consequences }\end{array}$ \\
\hline \multirow[t]{2}{*}{$\ln ($ Ownership Level) } & 0.201 & 0.111 & 0.252 & 0.197 & 0.183 & 0.115 \\
\hline & $(0.055)$ & $(0.037)$ & $(0.051)$ & $(0.048)$ & $(0.047)$ & (0.049) \\
\hline \multirow[t]{2}{*}{$\ln$ (Firm Employees) } & 0.163 & 0.128 & 0.167 & 0.164 & 0.174 & 0.137 \\
\hline & $(0.025)$ & $(0.022)$ & $(0.026)$ & $(0.025)$ & $(0.021)$ & $(0.022)$ \\
\hline \multirow[t]{2}{*}{ Firm age } & -0.001 & -0.001 & -0.001 & -0.000 & -0.001 & 0.000 \\
\hline & $(0.001)$ & (0.001) & $(0.001)$ & $(0.001)$ & $(0.000)$ & (0.001) \\
\hline \multirow[t]{2}{*}{$\ln$ (Number of group affiliates) } & 0.029 & 0.013 & 0.017 & 0.022 & 0.032 & 0.054 \\
\hline & $(0.016)$ & (0.019) & $(0.021)$ & (0.019) & $(0.022)$ & $(0.017)$ \\
\hline Country Dummies (5) & Yes & Yes & Yes & Yes & Yes & Yes \\
\hline Two-digit industry dummies (19) & Yes & Yes & Yes & Yes & Yes & Yes \\
\hline Observations & 2,429 & 2,427 & 2,433 & 2,431 & 2,381 & 2,426 \\
\hline R-squared & 0.117 & 0.103 & 0.164 & 0.163 & 0.142 & 0.124 \\
\hline
\end{tabular}

Notes: This table examines the relationship between managerial practices supporting decentralization and organizational distance. Columns 12 relate to goal setting and columns 3-6 relate to performance review. The questions from the World Management Survey (WMS) are as follows: Column 1: "What is the motivation behind your goals and how are they cascaded down to the individual workers?" (WMS label: perf7). Column 2: "If your staff were asked about individual targets, what would they say?" (WMS label: perf10). Column 3: "What kind of indicators would you use for performance tracking?" (WMS label: perf2). Column 4: "How frequent do you review these performance indicators?" (WMS label: perf3). Column 5: "How are these performance review meetings structured?" (WMS label: perf4). Column 6: "What would happen if a follow up plan agreed during one of your meetings were not enacted?" (WMS label: perf5). Robust standard errors in narentheses. 
Table 5. Responsiveness to Industry Growth and Ownership Level

\begin{tabular}{|c|c|c|c|c|c|c|c|c|c|c|}
\hline \multicolumn{11}{|c|}{ Dependent variable: Sales Growth Affiliate - Sales Growth Standalone } \\
\hline & (1) & (2) & (3) & (4) & (5) & (6) & (7) & (8) & (9) & (10) \\
\hline & $\begin{array}{c}\text { No } \\
\text { Standalone } \\
\text { Control }\end{array}$ & $\begin{array}{l}\text { Matched } \\
\text { Standalone } \\
\text { Control }\end{array}$ & $\begin{array}{c}\text { Group } \times \\
\text { Industry FEs }\end{array}$ & $\begin{array}{l}\text { Controlling } \\
\text { for Equity } \\
\text { Stakes }\end{array}$ & $\begin{array}{l}\text { Wholly- } \\
\text { Owned }\end{array}$ & $\begin{array}{l}\text { Partly- } \\
\text { Owned }\end{array}$ & $\begin{array}{l}\text { Family } \\
\text { Groups }\end{array}$ & $\begin{array}{l}\text { Industrial } \\
\text { Groups }\end{array}$ & $\begin{array}{c}\text { Financial } \\
\text { Groups }\end{array}$ & $\begin{array}{c}\text { Great } \\
\text { Recession } \\
\text { Years (2008- } \\
2009)\end{array}$ \\
\hline$\Delta$ Industry Sales & $\begin{array}{c}0.521 \\
(0.025)\end{array}$ & $\begin{array}{l}-0.244 \\
(0.023)\end{array}$ & $\begin{array}{l}-0.260 \\
(0.023)\end{array}$ & $\begin{array}{l}-0.153 \\
(0.032)\end{array}$ & $\begin{array}{l}-0.243 \\
(0.026)\end{array}$ & $\begin{array}{l}-0.216 \\
(0.057)\end{array}$ & $\begin{array}{l}0.026 \\
(0.094)\end{array}$ & $\begin{array}{l}-0.149 \\
(0.039)\end{array}$ & $\begin{array}{l}-0.210 \\
(0.129)\end{array}$ & $\begin{array}{l}-0.182 \\
(0.036)\end{array}$ \\
\hline Ownership Level $\times \Delta$ Industry Sales & $\begin{array}{l}0.061 \\
(0.009)\end{array}$ & $\begin{array}{l}0.066 \\
(0.008)\end{array}$ & $\begin{array}{l}0.066 \\
(0.008)\end{array}$ & $\begin{array}{l}0.061 \\
(0.008)\end{array}$ & $\begin{array}{l}0.089 \\
(0.010)\end{array}$ & $\begin{array}{l}-0.001 \\
(0.017)\end{array}$ & $\begin{array}{l}0.033 \\
(0.024)\end{array}$ & $\begin{array}{l}0.042 \\
(0.010)\end{array}$ & $\begin{array}{l}0.085 \\
(0.030)\end{array}$ & $\begin{array}{l}0.085 \\
(0.009)\end{array}$ \\
\hline Share Equity Stakes $\times \Delta$ Industry Sales & & & & $\begin{array}{l}-0.112 \\
(0.027)\end{array}$ & & & $\begin{array}{r}-0.105 \\
(0.072)\end{array}$ & $\begin{array}{l}-0.186 \\
(0.034)\end{array}$ & $\begin{array}{l}0.021 \\
(0.104)\end{array}$ & $\begin{array}{l}-0.162 \\
(0.031)\end{array}$ \\
\hline $\begin{array}{l}\text { Ownership Level } \times \Delta \text { Industry Sales } \times \text { Dummy } \\
\text { for Crisis Years }\end{array}$ & & & & & & & & & & $\begin{array}{l}-0.128 \\
(0.015)\end{array}$ \\
\hline $\begin{array}{l}\text { Share Equity Stakes } \times \Delta \text { Industry Sales } \times \\
\text { Dummy for Crisis Years }\end{array}$ & & & & & & & & & & $\begin{array}{l}0.071 \\
(0.031)\end{array}$ \\
\hline Ownership Level & $\begin{array}{r}-0.135 \\
(0.004)\end{array}$ & $\begin{array}{c}-0.047 \\
(0.003)\end{array}$ & $\begin{array}{c}-0.046 \\
(0.003)\end{array}$ & $\begin{array}{c}-0.045 \\
(0.003)\end{array}$ & $\begin{array}{c}-0.051 \\
(0.004)\end{array}$ & $\begin{array}{l}-0.040 \\
(0.008)\end{array}$ & $\begin{array}{c}-0.045 \\
(0.010)\end{array}$ & $\begin{array}{c}-0.040 \\
(0.004)\end{array}$ & $\begin{array}{c}-0.036 \\
(0.010)\end{array}$ & $\begin{array}{c}-0.026 \\
(0.004)\end{array}$ \\
\hline Share Equity Stakes & & & & $\begin{array}{l}0.045 \\
(0.015)\end{array}$ & & & $\begin{array}{l}0.034 \\
(0.029)\end{array}$ & $\begin{array}{l}0.055 \\
(0.020)\end{array}$ & $\begin{array}{c}-0.006 \\
(0.048)\end{array}$ & $\begin{array}{l}0.037 \\
(0.015)\end{array}$ \\
\hline $\ln \left(\right.$ Sales $\left._{\mathrm{t}-3}\right)$ & $\begin{array}{c}-0.156 \\
(0.003)\end{array}$ & $\begin{array}{l}0.050 \\
(0.002)\end{array}$ & $\begin{array}{c}-0.053 \\
(0.002)\end{array}$ & $\begin{array}{l}-0.050 \\
(0.002)\end{array}$ & $\begin{array}{c}-0.051 \\
(0.003)\end{array}$ & $\begin{array}{c}-0.061 \\
(0.006)\end{array}$ & $\begin{array}{c}-0.054 \\
(0.006)\end{array}$ & $\begin{array}{r}-0.040 \\
(0.003)\end{array}$ & $\begin{array}{c}-0.047 \\
(0.008)\end{array}$ & $\begin{array}{l}-0.050 \\
(0.002)\end{array}$ \\
\hline Firm age & $\begin{array}{l}0.005 \\
(0.001)\end{array}$ & $\begin{array}{l}0.016 \\
(0.001)\end{array}$ & $\begin{array}{l}0.017 \\
(0.001)\end{array}$ & $\begin{array}{l}0.016 \\
(0.001)\end{array}$ & $\begin{array}{l}0.016 \\
(0.001)\end{array}$ & $\begin{array}{l}0.018 \\
(0.003)\end{array}$ & $\begin{array}{l}0.022 \\
(0.003)\end{array}$ & $\begin{array}{l}0.014 \\
(0.001)\end{array}$ & $\begin{array}{l}0.013 \\
(0.004)\end{array}$ & $\begin{array}{l}0.016 \\
(0.001)\end{array}$ \\
\hline$\Delta$ Industry Sales $\times$ Dummy for Crisis Years & & & & & & & & & & $\begin{array}{l}0.249 \\
(0.049)\end{array}$ \\
\hline Ownership Level $\times$ Dummy for Crisis Years & & & & & & & & & & -0.046 \\
\hline Share Equity Stakes $\times$ Dummy for Crisis & & & & & & & & & & $\begin{array}{l}(0.003) \\
0.015 \\
(0.015)\end{array}$ \\
\hline Corporate Group FEs & Yes & Yes & - & Yes & Yes & Yes & Yes & Yes & Yes & Yes \\
\hline 3-Digit Industry FEs & Yes & Yes & - & Yes & Yes & Yes & Yes & Yes & Yes & Yes \\
\hline Corporate Group $\times 3$-Digit Industry FEs & No & No & Yes & No & No & No & No & No & No & No \\
\hline Year-dummies & Yes & Yes & Yes & Yes & Yes & Yes & Yes & Yes & Yes & Yes \\
\hline Observations & 465,411 & 465,411 & 465,411 & 465,411 & 363,221 & 101,641 & 69,049 & 276,826 & 35,523 & 465,411 \\
\hline No. of corporate groups & 39,267 & 39,267 & 39,267 & 39,267 & 35,681 & 10,080 & 5,291 & 19,557 & 2,250 & 39,267 \\
\hline
\end{tabular}

Notes: This table presents results on how the difference in responsiveness to industry growth between group affiliates and standalone firms varies with the ownership level of the affiliate in the group. Industry growth is computed at the 3-year level and cover the period 2002-2011. Standard errors are robust to arbitrary heteroscedasticity through clustering by group affiliates. 
Table 6. Responsiveness to Industry Growth and Ownership Level: Variation by subsidiary characteristics

\begin{tabular}{|c|c|c|c|c|c|c|}
\hline \multicolumn{7}{|c|}{ Dependent variable: Sales Growth Affiliate - Sales Growth Standalone } \\
\hline & $(1)$ & (2) & (3) & (4) & $(5)$ & $(6)$ \\
\hline Moderating affiliate characteristic: & $\begin{array}{l}\text { Same } \\
\text { Industry }\end{array}$ & $\begin{array}{c}\text { Family } \\
\text { Managers }\end{array}$ & $\begin{array}{c}\text { Same } \\
\text { Ethnicity }\end{array}$ & $\begin{array}{c}\text { Board } \\
\text { Interlocks }\end{array}$ & $\begin{array}{c}\text { Overlap } \\
\text { Affiliate } \\
\text { Name }\end{array}$ & $\begin{array}{l}\text { Geographica } \\
1 \text { Region }\end{array}$ \\
\hline Ownership Level $\times \Delta$ Industry Sales $\times$ Dummy for Same Industry & $\begin{array}{l}-0.085 \\
(0.029)\end{array}$ & & & & & \\
\hline Ownership Level $\times \Delta$ Industry Sales $\times$ Dummy for Family & & & & & & \\
\hline Managers & & $\begin{array}{r}-0.073 \\
(0.027)\end{array}$ & & & & \\
\hline Ethnicity & & & $\begin{array}{l}-0.027 \\
(0.009)\end{array}$ & & & \\
\hline Interlocks & & & & $\begin{array}{r}-0.044 \\
(0.018)\end{array}$ & & \\
\hline Ownership Level $\times \Delta$ Industry Sales $\times$ Overlap Affiliate Name & & & & & $\begin{array}{l}-0.036 \\
(0.018)\end{array}$ & \\
\hline Ownership Level $\times \Delta$ Industry Sales $\times$ Dummy for Same Region & & & & & & $\begin{array}{l}-0.129 \\
(0.045)\end{array}$ \\
\hline Ownership Level $\times \Delta$ Industry Sales & $\begin{array}{l}0.067 \\
(0.011)\end{array}$ & $\begin{array}{l}0.068 \\
(0.009)\end{array}$ & $\begin{array}{l}0.085 \\
(0.011)\end{array}$ & $\begin{array}{l}0.055 \\
(0.009)\end{array}$ & $\begin{array}{l}0.068 \\
(0.012)\end{array}$ & $\begin{array}{l}0.071 \\
(0.010)\end{array}$ \\
\hline Ownership Level $\times$ Dummy for Same Industry & $\begin{array}{l}0.008 \\
(0.026)\end{array}$ & & & & & \\
\hline$\Delta$ Industry Sales $\times$ Dummy for Same Industry & $\begin{array}{l}0.167 \\
(0.076)\end{array}$ & & & & & \\
\hline Ownership Level $\times$ Dummy for Family Managers & & $\begin{array}{r}-0.024 \\
(0.013)\end{array}$ & & & & \\
\hline$\Delta$ Industry Sales $\times$ Dummy for Family Managers & & $\begin{array}{l}0.085 \\
(0.054)\end{array}$ & & & & \\
\hline Ownership Level $\times$ Dummy for Same Ethnicity & & & $\begin{array}{c}-0.004 \\
(0.005)\end{array}$ & & & \\
\hline$\Delta$ Industry Sales $\times$ Dummy for Same Ethnicity & & & $\begin{array}{r}-0.012 \\
(0.027)\end{array}$ & & & \\
\hline Ownership Level $\times$ Dummy for Board Interlocks & & & & $\begin{array}{l}0.009 \\
(0.005)\end{array}$ & & \\
\hline$\Delta$ Industry Sales $\times$ Dummy for Board Interlocks & & & & $\begin{array}{l}0.029 \\
(0.043)\end{array}$ & & \\
\hline Ownership Level $\times$ Overlap Affiliate Name & & & & & $\begin{array}{l}-0.013 \\
(0.005)\end{array}$ & \\
\hline$\Delta$ Industry Sales $\times$ Overlap Affiliate Name & & & & & $\begin{array}{l}0.014 \\
(0.043)\end{array}$ & \\
\hline Ownership Level $\times$ Dummy for Same Region & & & & & & $\begin{array}{c}-0.027 \\
(0.019)\end{array}$ \\
\hline$\Delta$ Industry Sales $\times$ Dummy for Same Region & & & & & & $\begin{array}{l}0.305 \\
(0.105)\end{array}$ \\
\hline Ownership Level & $\begin{array}{r}-0.031 \\
(0.004)\end{array}$ & $\begin{array}{r}-0.045 \\
(0.003)\end{array}$ & $\begin{array}{r}-0.045 \\
(0.005)\end{array}$ & $\begin{array}{r}-0.044 \\
(0.004)\end{array}$ & $\begin{array}{l}-0.037 \\
(0.004)\end{array}$ & $\begin{array}{r}-0.035 \\
(0.004)\end{array}$ \\
\hline$\Delta$ Industry Sales & $\begin{array}{c}-0.271 \\
(0.034)\end{array}$ & $\begin{array}{c}-0.241 \\
(0.025)\end{array}$ & $\begin{array}{r}-0.205 \\
(0.035)\end{array}$ & $\begin{array}{c}-0.238 \\
(0.026)\end{array}$ & $\begin{array}{r}-0.225 \\
(0.036)\end{array}$ & $\begin{array}{c}-0.296 \\
(0.030)\end{array}$ \\
\hline Firm Age & $\begin{array}{l}0.013 \\
(0.001)\end{array}$ & $\begin{array}{l}0.016 \\
(0.001)\end{array}$ & $\begin{array}{l}0.016 \\
(0.001)\end{array}$ & $\begin{array}{l}0.016 \\
(0.001)\end{array}$ & $\begin{array}{l}0.015 \\
(0.001)\end{array}$ & $\begin{array}{l}0.015 \\
(0.001)\end{array}$ \\
\hline $\ln \left(\right.$ Sales $\left._{t-3}\right)$ & $\begin{array}{l}-0.045 \\
(0.003)\end{array}$ & $\begin{array}{l}-0.050 \\
(0.002)\end{array}$ & $\begin{array}{l}-0.049 \\
(0.003)\end{array}$ & $\begin{array}{l}-0.050 \\
(0.002)\end{array}$ & $\begin{array}{l}-0.049 \\
(0.002)\end{array}$ & $\begin{array}{l}-0.054 \\
(0.003)\end{array}$ \\
\hline Dummy for Same Industry & $\begin{array}{r}-0.002 \\
(0.026)\end{array}$ & & & & & \\
\hline Dummy for Family Managers & & $\begin{array}{l}0.039 \\
(0.012)\end{array}$ & & & & \\
\hline Dummy for Same Ethnicity & & & $\begin{array}{l}0.014 \\
(0.015)\end{array}$ & & & \\
\hline Dummy for Board Interlocks & & & & $\begin{array}{l}-0.046 \\
(0.013)\end{array}$ & & \\
\hline Dummy for Overlap Affiliate Name & & & & & $\begin{array}{l}0.063 \\
(0.012)\end{array}$ & \\
\hline Dummy for Same Region & & & & & & $\begin{array}{l}0.051 \\
(0.044)\end{array}$ \\
\hline Corporate Group FEs & Yes & Yes & Yes & Yes & Yes & Yes \\
\hline 3-Digit Industry FEs & Yes & Yes & Yes & Yes & Yes & Yes \\
\hline Year-dummies & Yes & Yes & Yes & Yes & Yes & Yes \\
\hline Observations & 465,411 & 465,411 & 359,481 & 465,411 & 465,411 & 465,411 \\
\hline No. of corporate groups & 39,267 & 39,267 & 33,996 & 39,267 & 39,267 & 39,267 \\
\hline No. of affiliates & 119,772 & 119,772 & 92,385 & 119,772 & 119,772 & 119,772 \\
\hline R-squared & 0.333 & 0.331 & 0.324 & 0.331 & 0.322 & 0.326 \\
\hline
\end{tabular}

